\title{
Why things happen - Developing the critical realist view of causal mechanisms
}

\author{
John Mingers \\ Kent Business School, University of Kent, Canterbury, UK \\ j.mingers@kent.ac.uk
}

\section{Craig Standing}

School of Business and Law, Edith Cowan University, Perth, Australia

c.standing@ecu.edu.au

\begin{abstract}
Events happen within the organizational world not by chance but for reasons. It is surely the task of management research to try to explain why these events occur. This requires us to understand the nature of causality but, in general, this is seldom discussed in the management or IS literature. The standard, positivist view underlying statistical analysis is the Humean one of constant conjunctions of events leading to universal laws. Against this, many constructivists find the whole idea of external causality implausible. In this paper we explore a third alternative that is developing strongly within the philosophy of science, social theory and critical realism - the mechanisms view. This proposes that events are generated through the interaction of specific mechanisms endowed with causal powers that may or may not be triggered, and may or may not be countervailed. In particular, the paper develops some of the fundamental concepts such as the nature of events, emergent properties, the difference between properties and powers, casual interactions between levels, absences as causes, event causality and generative causality, and abstracting causal regularities. The paper concludes by illustrating these ideas with a series of empirical case studies.
\end{abstract}

Key Words: causality, mechanisms, emergent properties, powers

\section{Introduction}

Things happen in and around organizations. The organizational world is a constant flux of unfolding events which involve people, technology, materials, money, power, social structures and ideas. One of the primary purposes of management research is to understand and to explain these events. Assuming 
that one does not think that they simply happen by chance, and their patterned nature makes this statistically inconceivable, then one has to assume that there is some form of causation at work. However, within the broad ambit of information systems and management research there are several, largely exclusive, conceptualizations of causation. Moreover, it is a subject that, until relatively recently, has been little discussed within the management literature. Most research is carried out within a particular paradigmatic silo - positivist, constructivist, critical or realist - making implicit, but seldom justified causative assumptions.

Durand and Vaara (2009), in a stimulating paper, outline four general positions within the field of strategy although they can be applied equally to information systems. The positivist view that causation concerns empirically generated laws based on constant conjunctions of events; the constructionist $^{1}$ view that management research is more concerned with interpretation than explanation and therefore talk of external causes is somewhat spurious; the (critical) realist view of generative causality through the interactions of powerful mechanisms; and the pragmatist view that judges causal beliefs in terms of their instrumental values. After an analysis of the strengths and weaknesses of these positions, they go on to distil four conditions that they claim are necessary for an understanding of causality: i) that causation needs to be distinguished from constant conjunctions or statistical association; ii) that causation results from a complex interplay of mechanisms and forces; iii) that we must recognize the importance of social interventions and actors' constructions; and iv) that explanations have instrumental value depending on their explanatory power.

There is much in Durand and Vaara's approach with which we agree, and in this paper we wish to develop from it, highlighting what we perceive as limitations and developing more fully a particular approach to causation. This approach has grown from three different disciplinary fields - the philosophy of science, critical realism and systems thinking (Mingers, 2014). We shall call this approach a "mechanisms" view of causation as it is based on the idea that the events we observe and experience are generated through the complex interactions of generative mechanisms (or systems) that have causal powers or tendencies. This approach has been developing strongly within the philosophy of science (Illari \& Williamson, 2011) against the traditional hypothetico-deductive model which sees explanation as the deduction of consequences from general laws (covering law model). At the same time, although developed independently, it is a major component of Bhaskar's critical realism, and the idea of a mechanism is essentially the same as a system with emergent properties and powers. We should also point out, in case the idea of a "mechanism" sounds overly physicalist, that generative mechanisms or structures may be non-material, for example social structures, organizations, ideas, motivations and so on. In fact, anything that can be thought to have causal effects in the world. Moreover, there is not just one form of causation but many as Cartwright (1999, p. 119) argues -

\footnotetext{
${ }^{1}$ We will use the terms constructionist and constructivist inter-changeably.
} 
necessary conditions, sufficient conditions, agents, interventions, contraventions, modifications, enhancements, inhibitions etc.

The structure of the paper is to first review perspectives on causality in IS research in order to identify the weaknesses with current conceptualizations and management research more generally. Our preferred alternative - the CR mechanisms approach - has already been used in IS research but there is a good deal of confusion, not least because of Bhaskar's difficult, and often developing, ideas (Bhaskar, 1978, 1979, 1993, 2002; Bhaskar \& Hartwig, 2010). The main purpose of the paper is to develop the approach in a clearer and more consistent manner to facilitate its use in practice. This involves, in Section 3, clarifying concepts such as events, emergent properties, the difference between properties and powers, and causal interactions between different organizational levels and absences as causes. We then, in Section 4, describe the basic braiding between event causality and underlying generative causality including the possibility of abstracting generic causal regularities out of the analysis of specific episodic event. This theoretical approach is illustrated with an analysis of a series of empirical CR case studies and recommendations for practice.

\section{Current perspectives on causation}

Although causality has not been much researched within IS, there are some significant contributions that should be mentioned. One of the earliest was that of Markus and Robey (1988) who suggested three dimensions for the causal structure of theories: causal agency, logical structure and level of analysis. Before discussing these we should note that they are analyzing the causal structure of theories rather than discussing the nature of actual causation per se. Nevertheless, to the extent that theories are good theories, we should expect that their content corresponds with reality in some way.

In terms of the three dimensions, causal agency includes three possibilities - technology-driven, actordriven or emergent from a combination of both. Logical structure distinguishes between variance theories, which are essentially theories that relate outcomes to necessary and sufficient conditions at the same time (many statistical models are of this form), and process theories which look at contingent causal connections between events ("changes of state" in their terms) over time. This distinction is similar to the event/generative causality distinction we will make later. Level of analysis can be macro (society or organization), micro (individuals) or both. Although this was a useful framework in its time, it does not really capture more recent theoretical and philosophical developments, and is not directed primarily at causality.

Moving to Durand and Vaara (2009), we will analyze their four forms of causation. 


\subsection{Positivism/ empiricism}

It is still plausible to suggest that the dominant perspective in IS research is positivism despite the growth of qualitative, interpretive, critical and even post-modern research paradigms. For this reason, we will begin by looking at the assumptions made about causation within positivist research. Interestingly, the assumptions are inevitably made, but seldom discussed or even recognized. The standard view of the logic of explanation is the hypothetico-deductive model developed in the natural sciences (Hollis, 2002; Manicas, 2006; Rosenberg, 2008). The world is assumed to be governed by universal, general laws and science proceeds by uncovering these laws through repeated observations which lead, by way of induction, to a hypothetical law. Deduction is then used to make predictions from the laws and attempts are made then to observe the predictions and thus confirm or falsify the hypothesis. Generally, such laws are stochastic rather than deterministic and so statistical analysis of the data is necessary particularly, in management and econometrics, regression, structural equation modelling (SEM) or vector autoregression (VAR). Only events that are observable, and preferably measurable in some way, can form the basis of scientific analysis.

This view of deductive explanation rests on a particular philosophical understanding of causation formulated by David Hume (1978 (orig. 1739)), namely a constant conjunction of events. Hume was an empiricist and a sceptic and accepted as real only that which could be directly perceived. He therefore argued that, when we regularly see one event followed by another, e.g., a hammer driving a nail, and we say the hammer caused the movement of the nail we cannot mean anything more than that one event is always followed by another in a constant conjunction. There cannot be more to causation than that; there cannot be any further explanation in terms of something underlying or unobservable:

We may define a CAUSE to be 'An object precedent and contiguous to another, and where all the objects resembling the former are placed in like relations of precedency and contiguity to those objects that resemble the latter.' (p. 221)

Thus causation involves essentially two relations - precedence, one object or event must occur before the other, and contiguity, the objects must touch spatially. And, to distinguish causation from mere chance or coincidence, the conjunction must be constant - it must happen on each occurrence of similar circumstances.

Hume also suggested that, to the extent we think of causation as more than this, it is merely a psychological habit or custom that we have become used to: 
Again, when I consider the influence of this constant conjunction, I perceive, that such a relation can never be an object of reasoning, and can never operate upon the mind, but by means of custom, which determines the imagination to make a transition from the idea of one object to that of its usual attendant, and from the impression of one to a more lively idea of the other. (p. 221)

And second, that this is indeed, for Hume, the only possible way of conceiving causation:

“... experience only teaches us how one event constantly follows another; without instructing us in the secret connexion, which binds them together, and renders them inseparable."

Hume 1967

Thus the basic notion of causality that underpins positivism, and all the statistical analysis that goes with it, is one of simple event regularities. All that we can hope for in science is constant conjunctions of empirically observable and measurable events. Pearson, one of the founders of modern statistics, actually banned the notion of causation and he never again used the term causation in his work, declaring, "[o]nce the reader realizes the nature of such a table [a contingency table], he will have grasped the essence of the conception of association between cause and effect" (quoted in Pearl ${ }^{83}$ : 340). Equally, Hendry (1990, p. 184), a world-famous econometrician, accepted that: "I am a Humean in that I believe we cannot perceive necessary connections in reality. All we can do is set up a theoretical model in which we define the word 'causality' precisely, as economists do with $y=$ $f(x)$."

The problem is, that this is an extremely reductive and limited form of causation. We cannot really ask why things happen, or go beneath the surface of empirically observable conjunctions of events to discover the reasons for them (Bhaskar, 1978).

\subsection{Interpretivism/ constructionism}

Constructionists reject the Humean approach to causality as constant conjunctions leading to general laws because they view the social world as constituted by human meaning and see the main task of research as exploring and understanding subjective human viewpoints (Smith, 2006). From this perspective it becomes very difficult to have any approach to causality as objective since all explanations are merely personal or group viewpoints and have to be judged as equally valid: "there are no correct and incorrect theories but there are interesting and less interesting ways to view the world" (Walsham, 1993. P. 6). Indeed, Lincoln and Guba (1985, p. 27) found the concept of causality "repugnant because of its [negative] implications for free will". 
To the extent that interpretivist researchers do invoke claims of causality, then "explanations are causal, but not in the positivists' uni-directional sense; neither are they sought for the same purpose. Interpretive researchers posit circular or reciprocally interacting models of causality, with the intention of understanding actors' views of their social world and their role in it." (Orlikowski \& Baroudi, 1991, p. 14).

In practice, this position, taken strongly, is in many ways contradictory. Researchers do in fact make many ontological assumptions about the existence of people, organizations and technology, and they do theorize about the reasons why actors hold certain beliefs and the effects that they may have (Avgerou, 2013). This becomes very difficult without an alternative view of causality to the positivistic one that is rejected. It also makes the idea of any form of generalization very difficult and yet this is accepted by many interpretivist researchers (Lee \& Baskerville, 2012; Lee \& Hovorka, 2015; Walsham, 1995). As we shall see, we would argue that a way out of these dilemmas is the nonpositivist form of causation offered by the mechanisms approach. Indeed, this is also suggested by Avgerou (2013) in a very interesting paper proposing a mechanisms based approach specifically for interpretive research. We will discuss this more below.

\subsection{Realism}

Durand and Vaara's call the final two approaches to causation realist and pragmatist respectively but we do not agree with their characterization of either of these. Their description of a realist approach clearly stems from Bhaskar's $(1978,1979,1993)$ critical realism (CR) which itself developed in part from Harre and Madden (Harre \& Madden, 1975). This is based on a fundamental stratification of reality into the domains of the "real", the "actual" and the "empirical". The real is the external, intransitive world of mechanisms and structures that have properties and causal powers leading them to behave in particular ways. The interaction of these mechanisms, at different levels, generates the events that actually occur, or do not occur even though expected, forming the domain of the actual. Finally, a small subset of all the actual events is observed and recorded to become the empirical material of scientific research.

This form of causality is often called "generative causality" and is quite different from Humean causality. The events of the world that we observe and experience are generated by the interaction of systems or mechanisms which have their own particular structures and enduring causal powers. These powers may, at any particular time, not be exercised because they need triggering by particular circumstances or interactions; or they may be exercised but not result in any change because they are countervailed by some other mechanisms. We will consider these in much more detail later but we would just highlight two other important aspects (not mentioned by Durand and Vaara): that absences can be causes, and that human agents are obvious examples of mechanisms with causal powers. 
This leads to a methodology based on abduction rather than (or perhaps as well as ${ }^{2}$ ) induction or deduction. We make observations of the empirical world and then hypothesize possible generative mechanisms that could, if they existed, explain them. We then gather evidence to help us choose between them and identify the actually operative mechanisms. This approach rests on a transcendental argument - given how we experience the world, what must be the case in order to generate these experiences?

This critical realist view of causality has been employed in many management fields (Ackroyd \& Fleetwood, 2000; Edwards, O'Mahoney, \& Vincent, 2014) including marketing (Easton, 2010), information systems (Mingers, Mutch, \& Willcocks, 2013; Volkoff \& Strong, 2013; Wynn \& Williams, 2012; Zachariadis, Scott, \& Barrett, 2013), strategy (Kwan \& Tsang, 2001; Tsang \& Kwan, 1999; Watson, 2011)and organizational behavior (Reed, 2009; Vincent, 2008).

Durand and Vaara propose two criticisms of critical realism - what they term "inoperative transcendentalism", and an inability to reflect on the role of the researcher. Considering the first, the criticism is that it leads to such a complex mixture of actual and potential, operative and inoperative, causal mechanisms that it is not in practice possible to disentangle them. It seems to me that this is not really a valid criticism - the world is indeed complex and in trying to understand and explain it we may well have to consider multiple and inter-related causal possibilities. That it is difficult, and often fallible, does not mean that we should not attempt it. The second is strange indeed as among research methodologies $\mathrm{CR}$ is perhaps ablest to do this. First, because it recognizes that observations are always mediated, relative to historical, cultural and ultimately individual circumstances, and never pure reflection of reality. And second because is rejects the dichotomy between facts and values arguing that social science is unavoidably value-full and committed (Mingers, 1997).

\subsection{Pragmatism}

Durand and Vaara call on pragmatism as the next approach, partly in response to the criticisms discussed above. They see two main benefits of (Peircean) pragmatism (Peirce, 1905): against positivism, that it recognizes that you cannot completely separate observations of events from our meaningful interpretation of them. And against CR, that the abductive methodology generates knowledge that "is not objective in the traditional sense, but is context-specific and dependent on the perspective of the researcher" (p. 1249). However, both these points would be accepted by, and seen

\footnotetext{
${ }^{2}$ Peirce (1907), who developed the concept of abduction, saw scientific research as a combination of all three.
} 
as part of, critical realism. Indeed, CR's methodology is actually based on abduction although generally called, by Bhaskar, "retroduction".

Durand and Vaara conclude with four conditions constituting a grounding for causation: i) Causation must be distinguished from constant conjunctions and statistical association. ii) Causation results from a complex of interacting mechanisms. iii) The importance of the interventions and constructions of social actors must be recognized. iv) Causal explanations have instrumental value dependent on their explanatory power ("there's nothing more practical than a good theory"!).

We would agree with all of these, but claim that they are all integral to critical realism.

\subsection{Other categorizations within IS}

Within these very broad, and to some extent exclusive, research approaches, more specific forms of explanation have been identified. Hovorka et al (2008) discussed four forms: covering-law, statisticalrelevance (SR), contrast-class and functional. The covering-law model is essentially the deductivenomological (DN) approach of Hempel and Oppenheim (1948) where particular occurrences are deduced from general laws. The SR approach (Salmon, 1971) is the basis of most modern statistical analyses which seek to identify statistical relationships between various factors and the probability of occurrence of the phenomena to be explained. The contrast-class explanation (Van Fraassen, 1980), which can also be seen as the pragmatist view, recognizes that there may be several different explanations of the same phenomena dependent on the particular purposes or interests of the questioner. The functionalist form (Markus, 2004), which has been much criticized, explains the occurrence of phenomena in terms of the contribution they make to a wider system. This covers much of the technological design research. Hovorka et al (2008) surveyed the occurrence of these four explanation types in IS research and found that $75 \%$ of the papers used SR explanation, but as 93\% of the papers were positivist that is not particularly surprising. Salmon (1998), the originator of the SR model, has actually moved to a causal mechanisms approach.

Gregor and Hovorka (2011) also argue that causality is a much neglected subject. They recognize that there are many different approaches to causality but wish to maintain a basically realist ontology (against constructivism) and reject extreme relativism, asserting that it is possible to judge between viewpoints on the basis of better arguments (Toulmin, 1958).

They distinguish six approaches to causality, four drawn from Kim (2011), but some are just variants of others.

\footnotetext{
3 There is discussion about potential differences between abduction and retroduction in Bhaskar (2014) and O'Mahoney (2014)
} 
A1: Regularity analysis. This is essentially the constant conjunctions of events view.

A2: Probabilistic analysis. This is a form of non-deterministic regularity analysis. The lack of a closed system and unknown or unmeasurable effects mean that causal statements can only be made probabilistically.

B1: Manipulation analysis. This involves the deliberate (or perhaps accidental) actions of an agent bringing something about. The cause is an event that we can manipulate to create an effect, e.g., choosing a particular option in some software (Woodward, 2003).

B2: Mental (substantival) causation. This is really a variant of manipulation analysis but particularly concerns the creation of new objects or instruments. It involves the agents beliefs and ideas (Goldkuhl, 2004; Pearl, 2000).

C: Counterfactual analysis. This form of analysis argues that A is a cause of B if it is the case that, if A had not occurred then B would not have occurred. In other words, A is a necessary (but not sufficient) cause of B (Lewis, 1973). This is related to manipulation analysis in that one can deliberately bring about the occurrence or non-occurrence.

D: Enabling causal conditions. This approach focusses on the way in which particular characteristics of a mechanism, especially a designed artefact, may encourage or hinder subsequent actions. It can be formulated in terms of affordances (Gibson, 1977; Volkoff \& Strong, 2013).

Gregor and Hovorka go on to relate these forms of causal analysis to IS research in particular and, in a later paper, to design science (Gregor, Müller, \& Seidel, 2013).

\section{The mechanisms view in general}

The central idea of causation within critical realism is easy to state (Archer, Bhaskar, Collier, Lawson, \& Norrie, 1998; Bhaskar, 1978, 1979). Events, that is changes, that occur do so as a result of the interaction of relatively enduring mechanisms that have particular properties or causal powers. The mechanisms are not necessarily physical but could be social, psychological or conceptual, and may or may not be observable (Bunge, 2004). This "mechanisms" view of causality has been developing within the philosophy of science as well as critical realism as an alternative to the traditional Hempelian (Hempel, 1965) deductive-nomological (D-N) model of science (Gerring, 2007; Glennan, 1996; Glennan, 2002; Machamer, 2004; Machamer, Darden, \& Craver, 2000; Salmon, 1998; Symons, 2008). Apart from avoiding many of the problems besetting the D-N model, especially concerning induction, the idea of mechanisms fits much better with the actual practices of scientists (Bechtel \& Abrahamsen, 2005) and with explanations in everyday life (Mingers, 2014). 
The mechanism approach has also been developing within social science (Gorski, 2013). Hedstrom and Swedberg (1996) argued that mechanisms were the appropriate form of middle-range theories and identified three types - situational mechanisms that link macro level (society or organization) to micro level (individual); individual action mechanisms that link desires and beliefs with action opportunities at the micro level; and transformational mechanisms that link individual actions into wider intended or unintended effects at the macro level. They gave as examples the self-fulfilling prophecy (Merton, 1948), network diffusion (Coleman, Katz, \& Menzel, 1957), and threshold-based behavior (Granovetter, 1978) and showed that all of these actually embody the same underlying mechanism. Gross (2009) surveyed the use of mechanisms in social science and identified five different approaches including critical realist. He suggested that the use of mechanisms was actually very common but often implicitly without an explicit description of the mechanism (Smith, 2006). His own approach was based on American pragmatists such as Peirce (1992) and Dewey (1938) which is, as we shall see, is one of the sources of CR.

Astbury and Leeuw (2010) considered mechanisms within the context of evaluation studies. They built on Pawson and Tilley's (1997) work (which was itself based on critical realism) and identified three characteristics of mechanisms: that they are usually hidden and need to be uncovered in some way ("opening the black box"); that they are sensitive to different contexts; and that they generate outcomes or effects. A third source (although he did not use the term mechanism) is Senge's (2006) idea of systems archetypes - particular combinations of feedback processes, such as "success to the successful" or "limits to growth", that occur in many different context.

Finally, Avgerou (2013) has advocated the use of social mechanisms in social theory based IS research. Her idea is very similar to ours except in two significant ways: first, that she does not draw on critical realism in formulating her approach and, second, that she appeals to interpretivist (as opposed to positivist) researchers although she then finds difficulty in convincing them to accept the reality of causal mechanisms. Avgerou frames her approach using Markus and Robey's (1988) distinction between variance models that are essentially Humean and statistical, and process models that seek logical links in terms of events and actions. As Avgerou says:

"Thus, the development of explanation in interpretive IS research faces the difficulty of searching for causal processes of meaning making and action in the context-dependent unfolding of dynamic interactions of people with technology” (p. 403)

We suggest that the use of CR would actually alleviate the problem she faces. We argue that CR provides a sound underpinning for a mechanisms-based view of causality. CR provides a welldeveloped and comprehensive philosophical position that has mechanisms at its heart. It accepts the inevitable concept- and activity-dependence of social action, and thus the necessity of interpretation 
and hermeneutics, without committing the epistemic fallacy of restricting the ontology of the world to our conceptualizations of it. It has a place for both statistical analysis and meaningful interpretation (Mingers \& Willcocks, 2014; Mingers \& Willcocks, 2017).

\section{Developing the critical realist interpretation}

We can begin understanding CR's view of mechanisms with C. S. Peirce's (1958) concept of "abduction". This was a third form of logic complementary to induction and deduction (Psillos, 2009): "Abduction consists in studying facts and devising a theory to explain them" (5.145) and "abduction is the process of forming an explanatory hypothesis" (5.171). Thus, with abduction we begin with some particular occurrence that is perhaps unexpected, or does not agree with current theories, and we then imagine some possible theory or hypothesis that would explain the event. So, we are neither going from empirical examples to a general rule (induction) nor going from a rule or law to consequences (deduction) but instead generating a plausible explanation. More recently, this approach has been called in philosophy "inference to the best explanation" (Lipton, 2004) and "retroduction" by Bhaskar (1978). With CR, the particular form that these hypotheses take is potential generative mechanisms which, if they did indeed exist, would account for the observed events.

This relates to the fundamental distinction within CR between the domains of the real, which includes the actual which in turn contains the empirical (Bhaskar, 1978). The real is the domain of enduring causal generative mechanisms; the actual is the domain of transient events generated by the interactions of real mechanisms; the empirical is the subset of actual events observed and recorded for scientific purposes.

Mechanisms have a number of characteristics:

Mechanisms exist in a real, ontological sense independently of how they may be known or described by observers. They are stratified, in the sense of depth or hierarchy, and they may be physical, social, or conceptual. They may be observable or unobservable. Their existence is judged by a causal rather than a perceptual criteria - i.e., that they have causal effects in the world.

Mechanisms are relatively enduring in respect of the events that they cause but their absolute timescale may vary immensely. They have powers or tendencies, by virtue of their structural properties, to behave in particular ways or have certain effects. These powers may not be exercised all the time (perhaps needing to be triggered), or they may be exercised but have no effect because of the countervailing actions of some other mechanism. Through their interactions, mechanisms generate the actual occurrences and events of the world, only some of which are observed or noted empirically (Bhaskar, 1979, p. 170). Thus a mechanism may be said to consist of a structure of inter-related parts together with the powers or tendencies that the structure possesses. 
Social structures or mechanisms have different properties or characteristics to physical ones (Bhaskar, 1979). First, they only become manifest at all through the activities that they govern. That is, social structures cannot be directly observed, they exist only virtually as a set of practices or roles which govern or enable social activities - think of language as an example. Through these activities the structures become reproduced or indeed changed and transformed. Second, they rely to some degree on the knowledge and understanding of social actors who must be aware that they are doing a particular activity, and how to do it. Third, they are localized in time and space in the sense that they belong to particular cultures at particular times rather than being universal, apart perhaps from extremely general ones such as the human ability to use tools or language. Finally, social systems are inevitably open (rather than being able to be closed as in a laboratory experiment) and hence, in principle unpredictable.

Human beings are also clearly examples of generative mechanisms. They have a whole range of often complex powers to bring about various events, some being physical but others being cognitive, emotional or creative.

We should situate the idea of mechanisms within an overall critical realist research approach. Bhaskar's basic model for scientific research has five stages (DREIC) (Bhaskar, 1993, 2014) This has been extended to cover applied research to RRREIC (Bhaskar, 2010) (see Table 1).

Table 1 about here

These rather bare descriptions have been developed by several authors into more substantive procedures. Raduescu and Vessey (2008) have analyzed the three most common ones, those of Archer's (1995) morphogenetic approach, Danermark et al's (2002) six stage model and Pawson and Tilley's (1997) realistic evaluation framework. Within IS, Wynn and Williams (2012) have proposed a methodology specifically tailored to IS case studies, and Raduescu and Vessey (2009) have examined the importance of domain theories within CR methodology.

In the rest of this section we will describe and clarify the main concepts that form the critical realist view of causation. These are events, emergence, properties and powers, interactions between levels and absences as causes. Then, in the next section, we will put these together to give an overall account of causality as a braiding or intertwining of two forms - event causality and generative causality evaluated in terms of retrodiction and retroduction respectively. 


\subsection{Events: the actual and the real}

Before elaborating on causal mechanisms themselves, we need to move to the other side to consider the events that mechanisms generate. In critical realism this is the distinction between the domains of the Real and the Actual. In philosophical terms, there is a degree of debate about the nature of an "event" (Casati \& Varzi, 2002). Are they the same as or different to objects? Are there different kinds of events? Can there be static events or are all events time-bound? We broadly follow the approach of Quine (1970) and Goodman (1951) that objects and events are different but intrinsically related.

In general, the distinctions between objects (not necessarily physical) and events is that objects are "continuants", they exist in and through time persistently, but events are "occurrants", they take up time and may have different stages. Thus, an event has two aspects - a particular duration, a start and finish time, and some element of change in something; if nothing changes there is no event. We should note in passing that an absence may be an event - the missed train or the missed appointment where something was expected to occur but did not. If we begin with the idea of change, then what can it be a change of? Well, there is nothing other than the objects and structures in the domain of the Real that could change. There cannot be some other, ontologically distinct kind of thing. Thus events are just changes to existing entities. These changes could be to a single entity, for example a change in structure, and thus properties, or perhaps the generation or disintegration of the entity, or they could involve the interaction of several entities.

What is perhaps most important is the timeframe defining the event. We tend to think in terms of human timescales - births, deaths and marriages - but subatomic events take only nanoseconds while cosmic events may take billions of years. So there is no absolute time for an event - it depends on the nature of the event itself. But it also depends on the observer and their purpose in recording the event - we carve events out of the ongoing flux according to our interests. So we could consider the credit crunch as a single event, and look at its causes or effects, if we took a long view; or we could see it as an enduring mechanism spawning a variety of events if we took a week-by-week view.

Thus the picture that we have is of a variety of entities interacting with each other at a variety of hierarchical levels. The changes that occur to the entities we can call events depending on our viewpoint. Some of these entities form relatively enduring wholes through the continual, morphostatic interactions of their components. These entities also have more fleeting interactions in a contingent and short-lived way but the essence of the causal relationship is essentially the same.

\subsection{Causality as an emergent property}

In principle, the causal powers or properties of a mechanism result as an emergent property of the mechanism. Emergent properties themselves are seen as consequences of the structure of the entity - 
that is its component parts and their processes and relationships. Emergence is a long-standing concept within philosophy and is at the heart of the holism/reductionism debates. Elder-Vass (2005; 2010) has written a good explanation of emergence and a defense of emergent properties from a CR point of view and, in the main, we will follow his analysis.

An emergent property or power (we will discuss the difference later) is a property that is possessed by an entity as a whole but not by its parts. The emergent property results from the properties and relations of the parts. Many discussions of emergence assume physical systems but the concept can also be applied to social or cognitive ones. For example, the behavior of an economic market is an emergent property of the interactions of its buyers and sellers. Emergence implies a hierarchy of levels of systems. At any particular level, a system can be analyzed into its component sub-systems and their relations. These in turn can be further analyzed into components and so on down to the most basic forces. However, against reductionism, each level has its own degree of autonomy since it generates new properties which do not exist at the lower levels. A system is constituted by its structure of parts and relationships.

Elder-Vass distinguishes between systems with emergent properties which have what he terms "significant" structures, and systems that have only resultant properties because they have no significant structure. These are sometimes called "heaps" (Laszlo, 1972). Examples of heaps might be relatively arbitrary constructs such as "all the grains of rice in China", which do not have any actual relations; or properties of systems which are resultant rather than emergent since they are simply the sum of the properties of the parts - for example the weight of some grains of rice (which is a property of both the parts and the whole) or the average height of a group of people (which is a property only of the whole).

Elder-Vass also proposes a compositional view of emergence. This means that a system has its emergent properties and powers simply by virtue of its own structure. It does not require any other components, which do not necessarily belong to it, to exhibit its properties. This leads to a view of discrete bounded systems, each with their own particular properties or powers, dependent only on their own structures. There are two issues with this approach, particularly within the context of social systems. The first is that boundaries in social systems may not be easy to identify, or indeed be nonexistent. Or they may be identified differently by different observers (Mingers, 2014). Although clearcut boundary elements may not be identifiable, nevertheless social mechanisms do form for relatively enduring periods of time through processes of mutual influence and reinforcing causal relations.

The second is that some of the system's powers may actually only be realized in combination with some other mechanism(s), or may be inhibited by another mechanism. For example, in nature there are many examples of symbiotic relationships in which at least one of the organisms could not exist without the presence of the other. The same may be true with organizations (Amar, 2001; Modig, 
2007). They may develop to take advantage of a particular market opportunity, technology, software such as Google or Windows, or perhaps even just a project and no longer be sustainable when the situation changes. The same can be true of mechanisms within organizations. For example, Henfridsson and Bygstad (2013) identified mechanisms, such as an innovation mechanism and an adoption mechanism, that were both necessary in order to be successful.

Elder-Vass (2010) identifies another type of example - the power of water to put out a fire which is clearly only realized if there is a fire. However, this seems different. While it is true that water has certain properties (being cold and inflammable) that would put out a fire, would we want to say that is a power of water or merely an effect that happens if particular circumstances arise? This suggests that we should distinguish between properties or powers that are intrinsic to the mechanism regardless of its interactions, e.g., mass density or compressibility, and those that only occur within a particular interaction. We will discuss this later in terms of the mechanism and its context.

\subsection{Properties and powers}

In this section we wish to clarify the differences, if any, between terms such as property and power. In the critical realist literature, and particularly Bhaskar's own work, they tend to be used somewhat indiscriminately. Within philosophy, there is also a debate over whether powers and properties are the same. In positivism, causation is generally seen in terms of universal laws applied to rather inert objects but, as we have seen, in the mechanisms approach entities are seen as complex active systems with their own intrinsic powers (Chakravartty, 2008).

Considering properties and powers, we have seen that properties are the characteristics, attributes or behaviors of a system which result from the system's structure constituted by parts and their relations. For example, incompressibility is a property of water, indeed any liquid. Power is generally taken to mean the ability to affect or change something in the external environment thus, "water has the power to put out fire".

Several authors hold the view that properties are essentially the same as powers. For instance, ElderVass (2010, p.17) says, "Properties and powers may therefore be regarded as synonyms". Chakravarrty (2008, p.154) says, "I will use these terms [causal power, disposition, capacity] synonymously, to refer to properties of things in virtue of which they behave in particular ways in particular circumstances". And Bhaskar, although not generally very explicit about it, says "The ontological bases of powers are just the properties that account for them" (Archer, et al., 1998, p. 72).

Others, however, say they are distinct but related. Fleetwood (2009) suggests that there are those who give primacy to powers, e.g., Mumford (2008), Chakravartty (2008) and possibly Bhaskar; those who give primacy to properties, e.g., Bird (2008) and Mackie (1977); and those, including Fleetwood, who 
see neither as primary but both as intrinsically linked, e.g., Cartwright(1997) and Shoemaker (1997). I follow the latter group in that I argue that properties and powers are distinct, as we will see below, but that both come into being at the same time as characteristics of the particular thing or entity (the "thing" or "entity" may, of course, not be physical).

We suggest that a property is a characteristic of an entity or system that exists independently of other systems dependent only on the structure of the system. It may or may not be observed, or observable, and it may or may not be exercised at any particular time. In contrast, a power is the ability to generate or cause change in some other system. A power is thus relational - it describes the relation between a system and some other system or environment. A particular power depends on the properties of the system but also on the properties of the affected system. So, for example, water has the power to dissolve some substances such as salt and sugar (although in different ways) but not others such as oil or plastic. So the power of a mechanism to produce an outcome depends firstly on the properties of the mechanism and secondly on the context within which it operates. In terms of the relationship between the power and the property there can be multiple - a single property can generate a single power; several properties may be necessary to generate the power; or a single property may generate several powers.

We can illustrate with the example of a knife which has the power to cut things. For something to be a knife (or be used as a knife) there are two essential properties - it must have a sharp edge and a certain degree of hardness. The sharpness of the edge creates a high degree of pressure and the hardness is necessary to push through the material to be cut. Whether it actually does cut depends on the context, that is the other system(s) with which it is interacting - even a steel knife will not cut diamond. It is not necessary that the object has been designed to be a knife - a sharp flint can also cut as it has the necessary properties. So here, we have two properties generating a single power.

We can also have the situation where a single property can lead to different powers depending on what the mechanism interacts with. Consider the property of being acidic. Acids are chemicals that tend to lose a hydrogen ion in solution; bases tend to gain an ion so there is one emergent property (that can be realized in a variety of different chemicals) but it can display different powers. For example, acids in the stomach break down food; acid rain destroys the environment; acetic acid (vinegar) preserves food; and acids burn the skin.

Finally, we can have a single property generating a single power, for example the mass of a hammer giving it the power to drive in nails.

Used in this way a power is very similar to the concept of an "affordance". This term originated in psychology where Gibson (1977) used it to mean what is offered or provided for someone by an object. It have been taken up in IS to describe the opportunities or possibilities provided by a 
particular technology (Leonardi, 2011; Majchrzak, Faraj, Kane, \& Azad, 2013) and Volkoff and Strong (2013) and Bygstad et al (2016) have employed the term explicitly in the context of generative mechanisms. An affordance is relational as it concerns the relation between the object and the other object or actor so an object or technology may have different affordances with different actors.

Another term of relevance is "liability". This is really the obverse of a power. If a knife has the power to cut cheese, then cheese has the liability to be cut by the knife. If the cheese were a suit of armor then it would not have that liability at least with respect to the knife. So a liability is a negative power - the power to be affected in a particular way by some other causal power.

\subsection{Causal Interactions between levels: Mechanisms in context}

So far we have been primarily concerned with what might be called "upward causation", i.e., the manner in which the structure of a mechanism, its components and their relations, generate the properties and powers of the whole. But in many systems, especially social systems, there appears to be "downward" causation as well - that is the structure of the whole can affect the behaviors of the components. Critical realism clearly accepts this with its concept of holistic causality (this is a $3 \mathrm{~L}$ concept within critical realism's MELD framework (Bhaskar, 1993)) but there are certain issues. First, there is a question of logical levels - can a higher level system interact with its own components or can it only interact with other entities at the same level? Second, strong reductionists object since they believe that higher level states should always be explicable in terms of lower level ones. And, third, it can easily be seen as a form of functionalist explanation which many social scientists see as illegitimate. An approach which can overcome these problems is to argue that the states of the system as a whole condition or affect the states of the lower level components by enabling or constraining the paths of behaviors that they can have without actually determining them.

Within social science, there are different positions on this, from individualists such as King (1999, 2000) who argue against the causal effects of social structure, through structurationists such as Giddens (1984; Jones \& Karsten, 2008)who see a duality of social structure and individual action, to realists such as Archer (2003) who see two independent systems in interaction. From the mechanisms perspective we would support the realist or at least the structurationist positions (to the extent there is in fact a difference between them (Mingers, 2004)) and can suggest some practical models which help in identifying potential mechanisms.

The first is the macro-micro-macro model developed originally by Coleman (1986). He argued that in trying to understand change in social structures it was necessary to identify three distinct causal episodes: beginning with macro level social changes which structure micro level interactions between people which in turn, at a later date, reproduce or transform the macro level structure. Hedstrom and 
Swedberg (1996) termed these three types of mechanisms situational, individual action and transformational respectively. Astbury and Leeuw (2010) give an example, based on Pawson (2006), of the "naming and shaming" of sexual offenders. In the macro-micro phase, mechanisms such as agenda setting and information diffusion raise awareness and increase knowledge of the problem. Then in the micro-micro phase, mechanisms such as joined up surveillance by a wide range of citizens and officials lead to a greater amount of information about suspicious behavior. Finally, in the micromacro stage, it is hoped that opportunity reduction and offender shame will lead to a lessening of the objectionable behavior.

Another example is the "tragedy of the commons" (Hardin, 1968) which can be seen to apply in many ecological and sustainability contexts. At the macro level, a resource is available at little or no cost to those who want to use it. Individuals then act at the micro level in their own particular interest using the resource. Because there is no overall control, the result is that all of the resource is used up. This can be seen in many situations, for example over-fishing, over-use of water reserves or the pollution of the atmosphere.

A more specifically critical realist approach that echoes the macro-micro-macro model is Archer's (1995; 2003) morphogenetic model of social action. For Archer, there are two separate but interacting systems - social system and social action. The relationship between the two, unlike in the case of Giddens structuration theory, is temporal. What this means is that there is a cycle - social structure at time $\mathrm{T} 1$ predates social action at time $\mathrm{T} 2$, but then the social action leads to either a change in (morphogenesis) or maintenance of (morphostasis) the social structure at time T3. In fact, society is seen to consist of two related systems each with its own emergent properties. The structural system is based on agential interactions that concern resources while the cultural system is based on interactions that concern ideas (Archer, 1988). These are based on structural emergent properties (SEPs) and cultural emergent properties (CEPs) respectively. There are, thirdly, the emergent properties of human beings (PEPs) (Archer, 2000).

Thus, at $\mathrm{T} 1$ the already existing system provides conditioning for human action in terms of a structure of roles, practices and ideas. These enable and constrain activity, but do not determine it. At T2, socio-cultural interaction occurs where agents act based partly on the situational logic in which they find themselves and partly on their own internal psychological states. Archer (2007) stresses the role of reflexity and the "internal conversation" in influencing the choices that actors make (Mutch, 2010) and the reasons why different actors may make different choices within the same situation. Finally, at T3, the social action may lead to morphostasis, reinforcing the existing social system, or it could lead to change in either the cultural or structural sphere or both. As can be seen, this model is very similar in approach to Coleman's. 
A third model is discussed by Bhaskar (2014) which recognizes that there may in fact be several levels of system involved in a particular context, what is called "laminated systems". These may be laminated systems conceptualized for a specific situation. For example Bhaskar and Danermark (2006) carried out a study of disability and found it necessary to identify seven distinct levels, from the physical and biological up to the socio-cultural and normative. Brown (2009), in a study of education, employed physical, psychological, socio-cultural and curricula. Similar approaches have been used in the study of climate change (Bhaskar, 2010). One obvious consequence of this is the need for inter-disciplinary research as these level cross traditional disciplinary boundaries.

We can also see laminated systems models that are more generic, for example, Bhaskar's (1993) fourplanar model of social activity. This suggests that all social activity occurs simultaneously in four dimensions: i) interactions with the physical and technological world, ii) interactions with other people, iii) interactions with the higher level social system, and iv) stratified levels within the embodied personality.

One consequence of the openness of social systems is that in general we will not be able to specify how a mechanism will behave without considering its context, that is the other mechanisms that are also operating at the same or at different hierarchical levels. So as well as explaining mechanisms in terms of the underlying structures that generate them we need to specify the enveloping context or field of operations. Considering the two together leads to the output that they produce. Pawson and Tilley (1997) express this in their Context, Mechanism, Output (CMO) model and Bhaskar (2014) further developed this to include Structure (CSMO). In the process of investigating such systems there needs to be a constant interplay between retrodiction and retroduction in moving from events that are to be explained to potential explanatory mechanisms to possible consequences of those hypothetical mechanisms.

\subsection{Absences as causes}

We have mentioned several time the idea that causation is not just positive, i.e., limited to relations between positively occurring events or entities. We also maintain the common-sense view that absences of either things or events may be causes. This is a central part of Bhaskar's ontology, namely that reality consists just as much of absences as positive presences (Bhaskar, 1994, pp. 56-57). By this, he does not mean things that were believed to exist but actually do not such as phlogiston, but rather something which could or should be there but is not. This is not universally accepted positivism generally only considers real that which actually exists and may be perceived or measured while Armstrong (1999, p. 177) argues that "Omissions and so forth are not part of the real driving force in nature. Every causal situation develops as it does as a result of the presence of positive factors alone". However, we argue that the sheer ubiquity of such events (or lack thereof) makes it impossible 
not to accept that absences can be causes. The fire-door not closed worsens the fire; the plant not watered dies; the unpaid bill causes the electricity to be cut off; the drought causes people to die.

It might be objected that this is merely a semantic matter of which state we choose to name and that there is in fact symmetricity between the two, but this is not the case. For example, "baldness" is defined as the absence of hair, but "hairiness" is not defined as the absence of baldness. The norm is that there is hair, and so baldness is an absence of the norm or expectation.

Indeed for Bhaskar, certainly since the development of dialectical critical realism (Bhaskar, 1993), absence is as fundamental as presence and he identifies a third fallacy of positivism (after the epistemic fallacy and the fallacy of ontological actualism) as being what he calls ontological monovalence:

"In contrast to this, dialectical critical realism argues that absence is constitutively necessary for being. A world without absence, without boundaries, punctuations, spaces, and gaps between, within and around its objects would be a world in which nothing could have determinate form or shape, and in which nothing could move or change, and in which nothing could be differentiated or identified"

(Bhaskar, 2010, p. 15)

However, we have to be careful to restrict our absences in some way. At any time and place there is an infinity of events that are not happening and entities that are not present but they only become of causal relevance when there is an expectation that they would have been present and their absence changes how the world would have been expected or desired to be. It is also the case that in some situations an absence is actually necessary - a sponge needs holes (absence of material) in order to soak up water; the vacuum flask need a vacuum (absence of air) to keep warm. We can distinguish a simple absence of an object or event (Bhaskar calls this a "de-ont") and also an absenting action draining flood water for example. Bhaskar (1994) calls these "product" and "process" respectively. For example, the absence of particular functionality or information in an IT system may lead to a process of redesign or, conversely, a system may produce too much irrelevant information and action may need to be taken to absent this.

The idea of absences as causes is related to the counterfactual theory of causation (Lewis, 2013). This holds that, if we have two events or entities A and B, causal claims are of the form "If A had not occurred then B would not have occurred". If A is a necessary (although not necessarily sufficient) condition for $\mathrm{B}$, then the absence of A can be said to cause the absence of $\mathrm{B}$. Of course, there may be other causes of the absence or presence of B as well. This can occur both in terms of events (not attending the exam caused not passing the exam) and mechanisms (not having a charged battery caused the car not starting) as we will discuss in the next section. 
This approach is central to the idea of retroduction. In explaining an event we seek hypothetical mechanisms that might generate it, but we could also be looking for mechanisms the absence of which generates the event, or indeed both. Consider a building catching fire - we would be interested in both mechanisms that triggered the fire - dropped matches, a faulty appliance - but also the absence of mechanisms which, if they existed, might have put it out - sprinklers or fire alarms for example. I write this just after the dreadful Grenfell tower block fire. It was started by a faulty fridge freezer and spread so rapidly because of an absence of sprinklers and the presence of highly flammable cladding.

\section{Event causality and generative causality: Retroduction and retrodiction}

Having discussed the various elements involved - mechanisms, properties, powers, levels and events we can now put together the whole picture in terms of two forms of causality that are always in play together - event causality and generative causality. In any situation where changes are occurring, there will be a series of linked events, one (or more) leading into the next. We can then answer the question "what caused event $\mathrm{Z}$ to happen?" in terms of preceding events, $\mathrm{A}, \mathrm{B}, \mathrm{C}$ etc. which will, in varying ways, be necessary or sufficient for the following event(s). This is the basis of Humean causation as constant temporal conjunctions of events. However, although this analysis attempts to answer the question "what caused $\mathrm{Z}$ to happen" it does not answer the why question - why did Z happen and not something else? To answer this we have to examine the characteristics and properties of the mechanisms that are involved in the events so that we can explain the particular event as following from the causal powers of these mechanisms. This is generative or mechanism causality. Another way of distinguishing between the two is that event causality is diachronic, the relationship is sequential in time, and generative causality is synchronic, properties explain the behaviors at the same time.

This fundamental distinction is essentially the same as that made by Aristotle as efficient/material, Salmon (1998) as etiological/constitutive and Bhaskar (1994) in terms of retrodiction/retroduction.

Within CR, the heart of this is the distinction between the Actual and the Real and the idea that mechanisms in the domain of the Real generate events within the domain of the Actual. Another way of putting this is that we need to talk about both "real" and "actual" causation:

"Real and actual causation both therefore appear to be consequences of the same generic type of structural relation: the (diachronic) causal consequences that flow from a given set of entities existing (synchronically) in a given set of relations to each other." \{Elder-Vass, 2005 \#2338, p. 355 
Real causation involves the powers and tendencies that complex mechanisms embody whether these are actually realized on any particular occasion, or whether they are counteracted by some other mechanism. These are the properties and powers that we have analyzed above as emergent from the mechanisms' structure. Mechanisms have these powers whether or not they are actualized and whether or not they are observed.

In contrast, actual, or event, causation concerns the relationships over time between one event and another. This form of causality (at least in the social world) is never determinate but always multiple and contingent - the unpredictable outcome of a range of interacting mechanisms at different levels. This is where laboratory science is different since in the lab it is possible to control many of the extraneous factors and set up constant conjunctions of events such that $\mathrm{X}$ is always followed by $\mathrm{Y}$ since there is nothing to interfere with it or countervail it.

Thus, events in the real world happen, or do not happen, through the interaction of a variety of different causal mechanisms, each with their particular causal powers and liabilities. However, as we have seen, mechanisms are composed of components and while mechanisms have a domain of interactions as a whole, they also interact with each other, at the same time, through their components. So, when I meet someone I respond to them as myself and as themselves (as wholes) but I also shake their hand and smile with my face, and perhaps sub-consciously notice something (sub-conscious) about their body language. All of these complex interactions, at different hierarchical levels, come together to generate the actual event that occurs.

Within the CR tradition the main inferential method has been retroduction, which is what we have called generative causality. However, Bhaskar has also used the term retrodiction (as contrasted perhaps with prediction), for example in RRREIC, to mean what we have termed event causation. Retroduction can be particularly aligned with theoretical research where we have a lack of explanatory knowledge in a particular context and are trying to discover the underlying causal mechanisms generating the phenomena of interest. Retrodiction is more applicable in applied settings where we do have some understanding of the mechanisms in play and want to use them as part of a causal account of why certain events have or have not happened.

"We engage in retroduction when we are relatively ignorant about the mechanisms in operation that are causing the phenomena under investigation ... Retroduction usually involves asking a specific kind of question: 'what thing, if it existed, might account for the existence of $P$ ?' ... There are times however when we are not ignorant, but relatively knowledgeable of the mechanisms in operation that are causing the phenomena under investigation. ... In this case we use existing theories, observations, claims and other knowledge to retrodict, that is, make claims about the way these mechanisms tend to operate perhaps in combination with other mechanisms, and perhaps in important contexts, to bring about Q" 
(Fleetwood \& Hesketh, 2010, p. 243)

We should not see these two inferential approaches as alternatives - one or the other - for in many situations, especially in the open world of the social sciences, we may be trying to do both by generating new knowledge as well as applying it to a particular context (Steinmetz, 1998).

"In such circumstances the applied explanatory task of discovering antecedent states of affairs, involving retrodiction, will have to go hand-in-hand with the explanatory theoretical task of discovering the nature of the relatively enduring generative mechanisms at work, involving retroduction."

(Bhaskar, 2010, p. 6)

Moreover, the task of social explanation can develop into an action-oriented mode of research (action research) with the aim of bringing about improvements to social and organizational situations - a process of learning about and changing the world (Bhaskar, 2014, p. ix)

To illustrate the argument simply let us imagine a scenario - Bob is in the kitchen and puts down a glass vase on the worktop; Sue is unaware of this and turns round, knocking into the vase; the vase falls to the floor and breaks.

We can begin by looking at this diachronically. We can see the whole as a single event - the vase getting broken - but we can also split it into several separate but related sub-events. Although this split is to some extent arbitrary, nevertheless it is possible because we can see that each sub-event could have had a different outcome, and that if it had the result would have been different. In this case we could split it into four sub-events: putting down the vase, turning round, knocking the vase, and it falling to the floor and breaking. Each of these sub-events could have had a different outcome. Bob could have put the vase down loudly so that Sue knew it was there; he could have put it in another place out of range; Sue could have moved differently and so not come into contact with the vase; it might not have been a vase she came into contact with but the kettle which would not fall off; Sue might have caught the vase; it might not have broken; if the vase had been a rubber ball it would have bounced; if it had been a sharp knife it might have cut Sue and so on.

What we can see here is a series of events each one of which sets up the conditions for the next one but does not wholly determine what the next one will be. The conjunction of all four of the events is a sufficient cause of the vase breaking (assuming no other countervailing events have occurred) but it is not a necessary cause as something else could have caused it to break, say a cat jumping on the worktop. In terms of the individual events, we can see that one event does not cause, in the sense of determine, the next event. Rather, it sets up the conditions for the next interaction, but what actually happens depends both on the conditions, and the properties and powers of the interacting systems. 
Synchronically, we can see that at each event particular systems interact, both as wholes and parts, and generate a particular outcome, which could always have been different. Thus, in event 1 the vase was placed at a particular position, and in such a way that it made little noise. Had it been put down in a different place, or more noisily, the later outcomes might not have occurred. When the vase fell off, it broke because of its relative fragility and the force of collision. Had it been made of a different material, or fallen from a lower height the outcome again might have been different.

In each case, we can see that the result is nothing other than a change on the configuration of the systems involved, whether that is a spatial change or, in the case of the vase, disintegration. The events are changes to the mechanisms which are, relatively speaking, more enduring.

These distinctions are summarized in Table 2.

Table 2 about here

\subsection{Abstracting causal relations - Demi-Regs}

Many of the examples of critical realist research are based on explaining the events in a single, or perhaps small number, of case studies. In addition, generally the CR approach does favor this with the emphasis on explanation not prediction, open systems and an antipathy towards constant conjunctions and universal laws. However, much of science, and potentially social science, is rightfully concerned with generalizing from particular instances to regular occurrences. In answering a question such as "what causes cancer?" we are more interested in factors that generate or perhaps prevent cancer in general than in why patient $\mathrm{X}$ got cancer.

Within CR, the main person to consider this is Lawson (1997, p. 204), in economics, who uses the concept of "demi-regularities" or demi-regs, which are:

"a partial event regularity which prima facie indicates the occasional, but less than universal, actualisation of a mechanism or tendency, over a definite region of time-space". 
So we are looking at a regularity that occurs over time and/or space. This could be caused by a single mechanism that exercises its powers regularly, for example the tide or the seasons, or it could be through a number of mechanisms that regularly interact in the same way for example daily traffic jams at rush hour. Or, it may be that is does not occur regularly but only whenever the right circumstances apply to trigger it. The question then arises as to how can we identify such patterns, and then generate potential causal explanations. If the situation is one where quantitative data may be produced then this brings in to play the role of statistics in critical realism (Mingers, 2006).

So far we have contrasted generative causality with the Humean view which actually underpins modern statistics. As we are all taught, correlation only implies association and not causation - there may be many reasons other than direct causation as to why two variables are associated in their values - and most statistical analysis remains in the domain of the empirical without venturing into the underlying domain of real causation. This has tended to give the impression that $\mathrm{CR}$ is actually antithetical to statistical modelling (Bhaskar, 1979; Lawson, 1997; Manicas, 1998; Porpora, 1998; Ron, 1999) although others have argued that it is not (Mingers, 2006; Pratschke, 2003).

However, there have been significant attempts to make the move from traditional statistical causality to generative statistical causality and the basic position adopted, for example by Pearl $(2000,2009)$, Woodward (2003) and Morgan and Winship (2007), is quite similar to our account of generative mechanisms. Pearl has made this transition personally:

"Ten years ago I was working in the empiricist tradition. In this tradition, probabilistic relationships [e.g. correlation, JM] constitute the foundations of human knowledge, whereas causality simply provides useful ways of abbreviating and organizing. Today my view is quite different. I now take causal relationships to be the fundamental building blocks both of physical reality and of human understanding" (Pearl, 2000, p. xiii)

And his formal position is very clearly stated:

"Nature possesses stable causal mechanisms that, on a detailed level of descriptions, are deterministic functional relationships between variables, some of which are unobservable." (Pearl, 2000, p. 43)

This tradition is actually not so recent, see for example Wright (1921), who first developed the idea of path coefficients in regression, and Haavelmo (1943), one of the founders of structural equation modelling. The specific idea here is to go from networks of relationships between variables, some observed and measured and some potentially unobservable, to deduce rigorously what must be the 
underlying mechanistic structure generating the observed network. The first step generally is to represent the network of potential causal effects graphically in a form of influence diagram. The relationships may be based both on observations and also prior theory. Within the graph, nodes represent variables and arrows represent a variety of possible causal links - one-directional, bidirectional or underlying unobserved causal links affecting several nodes. In most analyzed cases the graph is directional in that some variables precede others, and does not cycle back on itself. Such a directional acyclic graph is called a DAG.

Overall this approach provides an interesting potential link between social mechanisms and more traditional forms of statistical modelling although there are clearly distinct problems. The first is that it is limited to variables that can be measured quantitatively with some form of functional or statistical relationship. The social world, being based on meaning, can often not be quantified or fitted neatly into a DAG. The second, particularly with Woodward's (2003) manipulationist approach, is that it is much more epistemic than ontological - it concerns our causal explanations and how we might know there is a causal influence rather than whether there actually is one.

\section{Analysis of empirical studies}

In this section we will analyses a range of empirical case studies that have explicitly used critical realism to see to what extent they utilize the concepts we have discussed above. The studies have been found from Google Scholar searches for "critical realism" or "critical realist" in journals that contain "information" in the title. Only papers with actual empirical cases have been included. The results are summarized in Table 3.

\section{Table 3 about here}

\section{Events}

The studies all analyze particular situations, as opposed to discovering general laws, but they cover a wide range from individual organizations to the adoption of broadband in rural areas to the development of ICT capabilities in a whole country. In each case they describe a series of events that needs explaining. These are very varied in timescale from a year or so to over 40 years which illustrates what was said about timescales being relative to the purposes of the researcher.

\section{Generative mechanisms}


Each study then discussed possible causal mechanisms generating the events although they differed in the degree of specificity and detail. Some, such as Henfridsson and Bygstad (2013) and Williams and Karahanna (2013) were explicit in identifying and describing specific mechanisms; others such as Njihia and Merali (2013) were more generic, in this case drawing extensively on mechanisms in Archer's morphogenetic theory (Archer, 1995; Archer, 2003). Several papers used Archer's theory and often, when they did, they tended not to use the term mechanism.

To give some examples of particular mechanisms: Henfridsson and Bygstad (2013) studied the rapid and successful development of a digital infrastructure within a Norwegian airline. They identified three mechanisms underlying this success - an innovation mechanism to generate new uses; an adoption mechanisms to encourage the take-up of the capabilities; and a scaling mechanism to allow for their rapid growth. Moreover, these mechanisms were also found to be present in a survey of other case studies of digital infrastructure. Williams and Karahanna (2013) studied the efforts that a large organization set up to help it coordinate its IT activities by way of a standing committee of business and IT managers, and an ad-hoc business process analysis task group. They hypothesized two mechanisms to explain the outcomes, a unit aligning mechanism at the macro-micro level and a consensus making one at the micro-micro level.

Several studies took a particular piece of software as the basic mechanism with the particular powers, affordances and liabilities that it brought as the explanatory factor. Zachariadis et al (2013) studied the adoption of the SWIFT inter-banking system over 30 years from 1973. SWIFT was a system for enabling inter-bank operations and was gradually adopted first by large banks and then by smaller banks. It had a range or powers and liabilities, for example it enhanced automation, speeded transactions and had effects on governance, but also needed to be aligned with other operations and was confined to the existing network. Volkoff et al (2007) studied the implementation of SAP within a large organization. They came to the view that the primary form of mechanism that generated change in practices was the embedding of routines into the software which in turn gave them a materiality beyond cognitions or practices. The most important components to be embedded were routines, data and roles. By being embedded in the software they became both more fixed and inflexible, and also more transparent and exposed. This led to changes in the way the organization worked, and these eventually in structural changes. In a later paper (Volkoff \& Strong, 2013), these effects were analyzed in terms of the theory of affordances.

Aaltonen and Tempini (2014) looked at the way in which very low level communication data automatically recorded in a system could be developed into usable marketing information defining a particular advertising audience. Three mechanisms were identified at different levels - the semantic closure mechanisms, embedded in the technology, produced stable metrics concerning user activity; the pattern-finding mechanism, at the level of database and statistical packages, identified relevant 
patterns in the metrics; and the framing mechanism, enacted by the managers, constructed scenarios and frames around the information to make it relevant and actionable. The approach largely involved retroduction rather than retrodiction.

The idea that large amounts of very low-level data could open up spaces of possibility for higher levels of emergence was also picked up in Iannacci's (2014) research into police-prosecutor routines. Iannacci (2014) did not specifically use the term "mechanisms" but it is clear that the analysis took routines as mechanisms that generated patterned sets of behavior in the interactions between police and prosecutors. It also took both IT and legislative artefacts as mechanisms that structured the routines. In fact, the situation is complex since the two types of artefacts interact with each other although they are at different levels in the analysis - IT is at the micro level, legislation is at the macro level. Changes in the IT artefacts triggered legislative changes to include technological interactions, and legislative requirements caused changes to the IT systems.

\title{
Levels of analysis
}

In terms of different levels of analysis, several papers explicitly referred to Coleman's (1986) macromicro-macro model, and Archer's morphogenetic cycle (which is essentially commensurate with Coleman) was also commonly used. For example, Dobson et al's analysis of failed broadband take-up analyzed mechanisms at three levels - Government and Federal regulatory initiatives, a particular organization created through these initiatives, and the social interactions at community level. Using morphogenesis, the study showed that structures at the organizational level such as social networking software conditioned the social activity at the individual level but this, in actuality, led to the rejection of the software (morphogenesis) and a reproduction of the country way of life (morphostasis). Mirani used Archer's models of both structural and cultural conditioning to examine three phases of the development of a finance company's relations to external, offshore IT suppliers. At each stage the prior structural and cultural conditions generated particular sets of actions which in turn led to later structural changes. One of the lessons was that many of the problems were due to a lack of recognition of the cultural differences rather than structural ones.

\begin{abstract}
Absence as cause
Consideration of absences as causes was limited in the papers, most not considering it. Of those that did, Njihia and Merali considered the common idea within development studies that lack of resources is one of the main inhibitors of progress but actually concluded that paying attention to what exists within developing countries in terms of local expertise, adaptive capabilities and needs is equally important. Dobson et al were not so much concerned with absence as a cause, but with absence as an effect - their question was, what was the cause of a lack of take-up of broadband just where you
\end{abstract}


might expect it to be welcomed? Looking to the future, one could see that the absence of take-up may well have negative effects in the future in an increasingly networked world.

\section{Event and generative causation}

All of the papers were concerned with the interactions of events and mechanisms, and particularly the way in which certain events can lead to or inhibit the later activation of particular mechanisms, which in turn then engender future events. And most pointed out the extent to which the activation or effects of particular mechanisms was dependent on the presence or absence of other mechanisms. Many of the papers used Pawson and Tilly's (1997) context, mechanisms, output (CMO) model to show how the outputs produced or not produced by a mechanism depended on its context.

However, none of the papers mentioned explicitly the distinction between retroduction and retrodiction although they often talked of retroduction and generally they also looked at sequences of events. I think that the explanation for this is that retroduction is a well-known concept, both from CR and from elsewhere, and it appeared early on in Bhaskar's writing but retrodiction is a more obscure term that has not figured so highly in the literature. Although it was mentioned in some of the earlier works there was little discussion of it. However, with more recent books actually applying the theory, such as Bhaskar et al (2010), Fleetwood and Hesketh (2010) and Edwards et al (2014) this should change and it certainly seems like a valuable distinction.

\section{Generalization}

Finally, two of the studies did make some attempt to abstract more general relationships. Henfridsson and Bygstad (2013) identified three causal mechanisms in their initial case study but then went on to look at 41 similar cases in the literature and were often able to identify the same mechanisms and to show that they only generated success if they occurred together. Zachariadis et al (2013) were examining the take-up and effects of the adoption of SWIFT in a large sample of banks. Through the initial, intensive, analytical work they were able to understand the ways in which the powers and liabilities of SWIFT might play out in different kinds of banks, e.g., large/small or early/late adopters. This enabled them to search for and find particular patterns of demi-regs in their data concerning the relationship between SWIFT adoption and successful performance.

Table 3 also shows the research methods employed in the studies. All of them were essentially intensive, relying on interviews, observation and participant observation. Various coding schemes were used in the analysis of the data, generally based on some form of grounded theory. But, this was generally supplemented by explicit theory as well. One study, Zachariadis et al (2013), explicitly used multimethodology as it also incorporated statistical analysis and econometrics. 


\section{Conclusions}

The nature of causality has been little discussed in social science, more specifically in management and IS research, which is very unfortunate since it is so central in trying to explain the occurrences of the organizational world. To summarize crudely, positivists have relied on a Humean view of causation in terms of constant conjunctions of events that can be analyzed statistically in an effort to discover general laws. The problem with this is that it remains at the empirical level of associations and statistical patterns - what happens - without being able to explain why it happens. Interpretivists reject this approach on the grounds that human action is always situated, meaningful and reliant on social constructions. The problem here is that causality becomes confined to our personal or social explanations of events, whether by lay people or researchers, rather than being granted ontological status.

In this paper we have argued for a third approach to causality that is being developed within a variety of disciplines including the philosophy of science, sociology, systems theory and critical realism. This view posits that the events that occur in the world, some of which we experience and then try to explain, come about as a result of the interplay of various mechanisms that exist and interact with each other. These mechanisms may be physical, social or conceptual, and may be observable or unobservable except through their effects. In particular, we have elaborated on the critical realist view of mechanisms since we believe that this provides the most thorough and consistent articulation of a mechanisms-based approach. The main benefits are: an important distinction between the domains of real, the actual and the empirical; a recognition of two intertwined forms of causality - event causality and generative causality - and correspondingly retrodiction and retroduction; an acceptance of the double hermeneutic of interpretivism; and an acknowledgement of the plurality of types of mechanisms and corresponding forms of research methods.

The specific contributions of the paper have been to develop more fully a range of concepts involved in the mechanisms approach - events, emergent properties, properties and powers, absences as causes, levels of interaction and mechanisms in context, and abstracting causal relations or demi-regs. And to then demonstrate these in a range of empirical case studies of information systems technology in organizations.

This hopefully clears the ground for future research into causal mechanisms which are harder to clearly identify in the social sciences than in the physical sciences. In particular, guidance would be valuable on how to identify possible causal mechanisms, how to deal with a variety of different levels of causality for example social, group, individual, psychological; how to deal with issues of multiple interpretation and understanding; whether generic mechanisms that recur in many situations can be identified; whether particular forms of social theory, for example Archer's morphogenesis or 
Giddens' structuration, are helpful; or how material and technological mechanisms interact with psychological and social ones. 


\begin{tabular}{|c|c|}
\hline DREIC for theoretical research & RRREIC for applied research \\
\hline Describe the events in a theoretically meaningful way & $\begin{array}{l}\text { Resolve complex events or phenomena into } \\
\text { component parts }\end{array}$ \\
\hline Retroduce hypothetical generative mechanisms & $\begin{array}{l}\text { Redescribe the events in a theoretically } \\
\text { meaningful way }\end{array}$ \\
\hline Eliminate alternative competing hypotheses & $\begin{array}{l}\text { Retrodict antecedent causal events and } \\
\text { retroduce hypothetical generative mechanisms }\end{array}$ \\
\hline Identify the correct mechanism(s) & Eliminate alternative competing hypotheses \\
\hline \multirow[t]{2}{*}{$\begin{array}{l}\text { Correct scientific knowledge in the light of the } \\
\text { (provisional) findings }\end{array}$} & Identify the correct mechanism(s) \\
\hline & $\begin{array}{l}\text { Correct scientific knowledge in the light of the } \\
\text { (provisional) findings }\end{array}$ \\
\hline
\end{tabular}

Table 1 Research methodologies for theoretical and applied research 


\begin{tabular}{|c|c|c|c|c|c|c|}
\hline $\begin{array}{ll}\text { Form of } \\
\text { Causality }\end{array}$ & $\begin{array}{l}\text { CR } \\
\text { Domain }\end{array}$ & Approach & $\begin{array}{ll}\text { Focus of } \\
\text { Analysis }\end{array}$ & Key Questions & $\begin{array}{l}\text { Abductive } \\
\text { Mode }\end{array}$ & $\begin{array}{l}\text { Research } \\
\text { methodology }\end{array}$ \\
\hline $\begin{array}{l}\text { Antecedent or } \\
\text { event } \\
\text { causality } \\
\text { (Diachronic) }\end{array}$ & Actual & $\begin{array}{l}\text { Diachronic } \\
\text { (history } \\
\text { taken into } \\
\text { account) }\end{array}$ & $\begin{array}{l}\text { Cause of } \\
\text { specific } \\
\text { events (i.e., } \\
\text { mechanisms } \\
\text { in context) }\end{array}$ & $\begin{array}{l}\text { How did the } \\
\text { combination of } \\
\text { mechanisms } \\
\text { interact to } \\
\text { generate a } \\
\text { particular } \\
\text { outcome in this } \\
\text { context? }\end{array}$ & Retrodiction & $\begin{array}{l}\text { RRREIC: } \\
\text { Resolution } \\
\text { Redescription } \\
\text { Retrodiction } \\
\text { Elimination } \\
\text { Identification } \\
\text { Correction }\end{array}$ \\
\hline $\begin{array}{l}\text { Generative or } \\
\text { mechanism } \\
\text { causality } \\
\text { (Synchronic) }\end{array}$ & Real & $\begin{array}{l}\text { Synchronic } \\
\text { (history not } \\
\text { taken into } \\
\text { account) }\end{array}$ & Mechanisms & $\begin{array}{l}\text { What generic } \\
\text { mechanisms } \\
\text { existed in this } \\
\text { phenomenon, } \\
\text { with what } \\
\text { properties and } \\
\text { powers, and } \\
\text { what do they } \\
\text { cause to occur? }\end{array}$ & Retroduction & $\begin{array}{l}\text { DREIC: } \\
\text { Description } \\
\text { Retroduction } \\
\text { Elimination } \\
\text { Identification } \\
\text { Correction }\end{array}$ \\
\hline
\end{tabular}

Table 2 Differences between event and generative causality 


\begin{tabular}{|c|c|c|c|c|c|c|c|c|}
\hline & Situation & Events & Mechanisms & $\begin{array}{l}\text { Levels of } \\
\text { interaction/ } \\
\text { CSMO }\end{array}$ & $\begin{array}{l}\text { Absences as } \\
\text { causes }\end{array}$ & $\begin{array}{l}\text { Event/ } \\
\text { generative } \\
\text { causality }\end{array}$ & $\begin{array}{l}\text { Abstracting } \\
\text { causal } \\
\text { relations }\end{array}$ & $\begin{array}{l}\text { Research } \\
\text { method }\end{array}$ \\
\hline $\begin{array}{l}\text { Mihailescu et al } \\
\text { (2013) }\end{array}$ & $\begin{array}{l}\text { A long-term } \\
\text { study of the } \\
\text { changes in IS } \\
\text { adoption } \\
\text { practices } \\
\text { specifically in } \\
\text { the context of } \\
\text { the enterprise } \\
\text { systems } \\
\text { implementation } \\
\text { methodology } \\
\text { (ESIM) for } \\
\text { SAP }\end{array}$ & $\begin{array}{l}\text { Four different } \\
\text { periods of } \\
\text { adoption } \\
\text { occurrences are } \\
\text { identified from } \\
1980 \text { to } 2004 \text { - } \\
\text { fragmented, } \\
\text { aggregated, } \\
\text { integrated and } \\
\text { infrastructural. }\end{array}$ & $\begin{array}{l}\text { Pre-existing } \\
\text { structural and } \\
\text { cultural } \\
\text { conditions } \\
\text { which then } \\
\text { affect ther } \\
\text { behavior of } \\
\text { individual } \\
\text { actors as } \\
\text { mechanisms }\end{array}$ & $\begin{array}{l}\text { Archer's } \\
\text { morphogenetic } \\
\text { model including } \\
\text { situational } \\
\text { logics at the } \\
\text { social level and } \\
\text { modes of } \\
\text { reflexivity at } \\
\text { the individual } \\
\text { level }\end{array}$ & & $\begin{array}{l}\text { Analyzed the } \\
\text { interplay } \\
\text { between time- } \\
\text { based } \\
\text { developments } \\
\text { in the } \\
\text { technology and } \\
\text { the effects and } \\
\text { consequences at } \\
\text { the interaction } \\
\text { level. }\end{array}$ & & $\begin{array}{l}\text { Retrospective } \\
\text { case analysis }\end{array}$ \\
\hline Iannacci (2014) & $\begin{array}{l}\text { The } \\
\text { development of } \\
\text { routines } \\
\text { governing the } \\
\text { interactions of } \\
\text { police and }\end{array}$ & $\begin{array}{l}\text { Changes, since } \\
2004, \text { in the } \\
\text { interactions } \\
\text { between police } \\
\text { and } \\
\text { prosecutors. }\end{array}$ & $\begin{array}{l}\text { Organizational } \\
\text { routines that } \\
\text { produce } \\
\text { recurrent } \\
\text { patterns of } \\
\text { behavior }\end{array}$ & $\begin{array}{l}\text { Used Archer's } \\
\text { morphogenetic } \\
\text { model } \\
\text { Recognized } \\
\text { three levels of } \\
\text { activity: }\end{array}$ & & $\begin{array}{l}\text { Recognition of } \\
\text { synchronic } \\
\text { interactions, } \\
\text { e.g., IT artefact } \\
\text { to IT aretfact, } \\
\text { and diachronic }\end{array}$ & & $\begin{array}{l}\text { Semi-structured } \\
\text { interviews, } \\
\text { focus groups } \\
\text { and interviews } \\
\text { over } 5 \text { years } \\
\text { Contrasts }\end{array}$ \\
\hline
\end{tabular}




\begin{tabular}{|c|c|c|c|c|c|c|c|}
\hline & $\begin{array}{l}\text { crown } \\
\text { prosecutors } \\
\text { based on } \\
\text { legislative and } \\
\text { IT artefacts }\end{array}$ & $\begin{array}{l}\text { From face-to- } \\
\text { face, to phone } \\
\text { calls to emails } \\
\text { to specific } \\
\text { computer } \\
\text { systems }\end{array}$ & $\begin{array}{l}\text { Legislative and } \\
\text { IT artefacts that } \\
\text { generate and } \\
\text { transform } \\
\text { routines }\end{array}$ & $\begin{array}{l}\text { Micro level } \\
\text { technological } \\
\text { interaction; } \\
\text { Meso level } \\
\text { person to } \\
\text { person } \\
\text { interaction; } \\
\text { Macro level } \\
\text { structural } \\
\text { conditioning/ } \\
\text { elaboration }\end{array}$ & & $\begin{array}{l}\text { interactions, } \\
\text { e.g., human to } \\
\text { human }\end{array}$ & $\begin{array}{l}\text { between } \\
\text { different sites } \\
\text { Iteration } \\
\text { between data } \\
\text { and theory }\end{array}$ \\
\hline Mirani (2013) & $\begin{array}{l}\text { The } \\
\text { development of } \\
\text { relations } \\
\text { between a } \\
\text { financial } \\
\text { company and } \\
\text { offshore IT } \\
\text { suppliers }\end{array}$ & $\begin{array}{l}\text { Over a six year } \\
\text { period three } \\
\text { different forms } \\
\text { of relationship } \\
\text { between the } \\
\text { organization } \\
\text { and the IT } \\
\text { suppliers each } \\
\text { involving } \\
\text { significant } \\
\text { organizational } \\
\text { change }\end{array}$ & $\begin{array}{l}\text { Did not discuss } \\
\text { specific } \\
\text { mechanisms but } \\
\text { used Archer's } \\
\text { framework of } \\
\text { social and } \\
\text { cultural } \\
\text { conditioning. }\end{array}$ & $\begin{array}{l}\text { Used Archer's } \\
\text { morphogenesis } \\
\text { to describe } \\
\text { structural } \\
\text { conditions } \\
\text { leading to } \\
\text { individual } \\
\text { interactions } \\
\text { resulting in } \\
\text { structural } \\
\text { change }\end{array}$ & & $\begin{array}{l}\text { Did not } \\
\text { explicitly refer } \\
\text { to event and } \\
\text { generative } \\
\text { causality but } \\
\text { both were part } \\
\text { of the analysis }\end{array}$ & $\begin{array}{l}\text { Long-term case } \\
\text { study involving } \\
\text { extensive } \\
\text { interviews with } \\
\text { the managers } \\
\text { involved in the } \\
\text { changes }\end{array}$ \\
\hline $\begin{array}{l}\text { Aaltonen \& } \\
\text { Tempini (2014) }\end{array}$ & $\begin{array}{l}\text { The use of data } \\
\text { tokens from a } \\
\text { telecoms }\end{array}$ & $\begin{array}{l}\text { The } \\
\text { identification } \\
\text { and shaping of }\end{array}$ & $\begin{array}{l}\text { Semantic } \\
\text { closure } \\
\text { mechanism }\end{array}$ & $\begin{array}{l}\text { The three } \\
\text { mechanisms } \\
\text { were at }\end{array}$ & $\begin{array}{l}\text { The failure to } \\
\text { update a } \\
\text { software tool }\end{array}$ & & $\begin{array}{l}\text { Mixed methods } \\
\text { - observations, } \\
\text { interviews, }\end{array}$ \\
\hline
\end{tabular}




\begin{tabular}{|c|c|c|c|c|c|c|c|c|}
\hline & $\begin{array}{l}\text { network to } \\
\text { create an } \\
\text { audience }\end{array}$ & $\begin{array}{l}\text { an audience for } \\
\text { advertising } \\
\text { from very low } \\
\text { level data } \\
\text { transactions } \\
\text { data }\end{array}$ & $\begin{array}{l}\text { Pattern finding } \\
\text { mechanism } \\
\text { Framing } \\
\text { mechanism }\end{array}$ & $\begin{array}{l}\text { different levels } \\
\text { from data } \\
\text { processing, to } \\
\text { data analysis to } \\
\text { organizational } \\
\text { activities }\end{array}$ & $\begin{array}{l}\text { led to the } \\
\text { absence of } \\
\text { adequate } \\
\text { information for } \\
\text { decision } \\
\text { making }\end{array}$ & & & $\begin{array}{l}\text { logs, } \\
\text { transmission } \\
\text { data, } \\
\text { photographs, } \\
\text { documents }\end{array}$ \\
\hline $\begin{array}{l}\text { Henfridsson \& } \\
\text { Bygstad (2013) }\end{array}$ & $\begin{array}{l}\text { Evolution of } \\
\text { digital } \\
\text { infrastructure }\end{array}$ & $\begin{array}{l}\text { Growth of } \\
\text { services, users } \\
\text { and } \\
\text { stakeholders }\end{array}$ & $\begin{array}{l}\text { Innovation } \\
\text { mechanism } \\
\text { Adoption } \\
\text { mechanism } \\
\text { Scaling } \\
\text { Mechanism }\end{array}$ & $\begin{array}{l}\text { Yes, need } \\
\text { interaction } \\
\text { between } \\
\text { mechanisms for } \\
\text { success. } \\
\text { Used CMO } \\
\text { framework }\end{array}$ & & & $\begin{array}{l}\text { A study of } 41 \\
\text { other examples } \\
\text { showed that } \\
\text { these same } \\
\text { mechanisms } \\
\text { were generally } \\
\text { present and } \\
\text { necessary for } \\
\text { success }\end{array}$ & $\begin{array}{l}\text { Interviewing, } \\
\text { participant } \\
\text { observation, } \\
\text { document } \\
\text { analysis, case } \\
\text { study survey }\end{array}$ \\
\hline $\begin{array}{l}\text { Williams and } \\
\text { Karahanna } \\
(2013)\end{array}$ & $\begin{array}{l}\text { Coordinating } \\
\text { practices within } \\
\text { a large } \\
\text { organisation }\end{array}$ & $\begin{array}{l}\text { Formation and } \\
\text { results of } \\
\text { coordination } \\
\text { bodies }\end{array}$ & $\begin{array}{l}\text { Consensus } \\
\text { making } \\
\text { mechanism } \\
\text { Unit aligning } \\
\text { mechanism }\end{array}$ & $\begin{array}{l}\text { Used macro- } \\
\text { micro-macro } \\
\text { and Archer's } \\
\text { morphogenesis } \\
\text { for relations } \\
\text { between low } \\
\text { level and high } \\
\text { level }\end{array}$ & & $\begin{array}{l}\text { Yes, events } \\
\text { change the } \\
\text { structure and } \\
\text { context }\end{array}$ & & $\begin{array}{l}\text { Longitudinal } \\
\text { case study. } \\
\text { Theoretical and } \\
\text { inductive } \\
\text { coding based } \\
\text { on grounded } \\
\text { theory }\end{array}$ \\
\hline $\begin{array}{l}\text { Zachariadis, } \\
\text { Scott and } \\
\text { Barrett (2013) }\end{array}$ & $\begin{array}{l}\text { Adoption of the } \\
\text { SWIFT banking } \\
\text { system }\end{array}$ & $\begin{array}{l}\text { Increasing } \\
\text { adoption and } \\
\text { question of }\end{array}$ & $\begin{array}{l}\text { SWIFT as a } \\
\text { mechanism } \\
\text { with causal }\end{array}$ & $\begin{array}{l}\text { Used the } \\
\text { powers and } \\
\text { liabilities of }\end{array}$ & & & $\begin{array}{l}\text { Identified demi- } \\
\text { regularities }\end{array}$ & $\begin{array}{l}\text { Interviews, } \\
\text { econometric } \\
\text { modelling, case }\end{array}$ \\
\hline
\end{tabular}




\begin{tabular}{|c|c|c|c|c|c|c|}
\hline & & $\begin{array}{l}\text { whether it } \\
\text { increased bank } \\
\text { profits }\end{array}$ & $\begin{array}{l}\text { powers and } \\
\text { liabilities }\end{array}$ & $\begin{array}{l}\text { SWIFT } \\
\text { Exercise of } \\
\text { powers in } \\
\text { particular } \\
\text { contextual } \\
\text { conditions, e.g., } \\
\text { large banks } \\
\text { different from } \\
\text { small banks }\end{array}$ & & studies \\
\hline $\begin{array}{l}\text { Volkoff and } \\
\text { Strong (2013) } \\
\text { Volkoff, Strong } \\
\text { and } \\
\text { Elmes(2007) }\end{array}$ & $\begin{array}{l}\text { Implementation } \\
\text { of SAP }\end{array}$ & $\begin{array}{l}\text { Six phases of } \\
\text { implementation } \\
\text { leading to } \\
\text { organisational } \\
\text { change }\end{array}$ & $\begin{array}{l}\text { SAP as a } \\
\text { mechanism for } \\
\text { organisational } \\
\text { change. Three } \\
\text { components: } \\
\text { - Routines } \\
\text { - Data } \\
\text { - Roles } \\
\text { embedded in } \\
\text { the technology }\end{array}$ & $\begin{array}{l}\text { Analysed } \\
\text { events in terms } \\
\text { of Archer's } \\
\text { morphogenesis } \\
\text { model. } \\
\text { Analysed } \\
\text { generative } \\
\text { mechanisms in } \\
\text { terms of } \\
\text { affordances } \\
\text { Emergence - } \\
\text { organisational } \\
\text { level from } \\
\text { micro level }\end{array}$ & & $\begin{array}{l}\text { Longitudinal } \\
\text { intensive case } \\
\text { study using } \\
\text { grounded } \\
\text { theory }\end{array}$ \\
\hline $\begin{array}{l}\text { Dobson, } \\
\text { Jackson and } \\
\text { Gengatharen }\end{array}$ & $\begin{array}{l}\text { Problems of } \\
\text { adoption of } \\
\text { broadband in }\end{array}$ & $\begin{array}{l}\text { Surprising } \\
\text { failure to } \\
\text { generate }\end{array}$ & $\begin{array}{l}\text { Archer's } \\
\text { communicative } \\
\text { reflexivity }\end{array}$ & $\begin{array}{l}\text { Macro-micro- } \\
\text { macro and } \\
\text { Archer's }\end{array}$ & $\begin{array}{l}\text { Deals with } \\
\text { absence of take- } \\
\text { up and its }\end{array}$ & $\begin{array}{l}\text { Longitudinal } \\
\text { case study, } \\
\text { interviews, }\end{array}$ \\
\hline
\end{tabular}




\begin{tabular}{|c|c|c|c|c|c|c|c|}
\hline (2013) & rural Australia & $\begin{array}{l}\text { broadband } \\
\text { adoption in } \\
\text { rural } \\
\text { communities }\end{array}$ & $\begin{array}{l}\text { valuing face-to- } \\
\text { face } \\
\text { interactions } \\
\text { Inability to } \\
\text { envisage } \\
\text { practical or } \\
\text { projective } \\
\text { broadband } \\
\text { opportunities }\end{array}$ & $\begin{array}{l}\text { morphogenesis. } \\
\text { Organizational } \\
\text { level } \\
\text { mechanisms } \\
\text { such as social } \\
\text { networking } \\
\text { software } \\
\text { conditioned the } \\
\text { social activity } \\
\text { at the individual } \\
\text { level but this, in } \\
\text { actuality, led to } \\
\text { morphogenetic } \\
\text { and } \\
\text { morphostatic } \\
\text { effects. } \\
\text { CMO } \\
\text { framework }\end{array}$ & effects & & $\begin{array}{l}\text { SSM, } \\
\text { Danermark's } \\
\text { CR framework }\end{array}$ \\
\hline $\begin{array}{l}\text { Njihia and } \\
\text { Merali (2013) }\end{array}$ & $\begin{array}{l}\text { ICT policy and } \\
\text { development in } \\
\text { Kenya }\end{array}$ & $\begin{array}{l}\text { Phases of ICT } \\
\text { development } \\
\text { between } 1963 \\
\text { and } 2006\end{array}$ & $\begin{array}{l}\text { Interactions } \\
\text { between } \\
\text { mechanisms at } \\
\text { the } \\
\text { political/govern } \\
\text { mental level, } \\
\text { international } \\
\text { organizations }\end{array}$ & $\begin{array}{l}\text { Extensive use } \\
\text { of Archer's } \\
\text { model including } \\
\text { especially } \\
\text { situational } \\
\text { logics }\end{array}$ & $\begin{array}{l}\text { Discusses the } \\
\text { relation } \\
\text { between } \\
\text { absences of } \\
\text { resources and } \\
\text { positive local } \\
\text { innovation and } \\
\text { development }\end{array}$ & $\begin{array}{l}\text { Shows how } \\
\text { developments } \\
\text { in events } \\
\text { opened up } \\
\text { spaces for new } \\
\text { mechanisms to } \\
\text { emerge. }\end{array}$ & $\begin{array}{l}\text { Longitudinal } \\
\text { case study } \\
\text { using structured } \\
\text { and } \\
\text { unstructured } \\
\text { interviews, } \\
\text { inductive } \\
\text { generalisation, }\end{array}$ \\
\hline
\end{tabular}




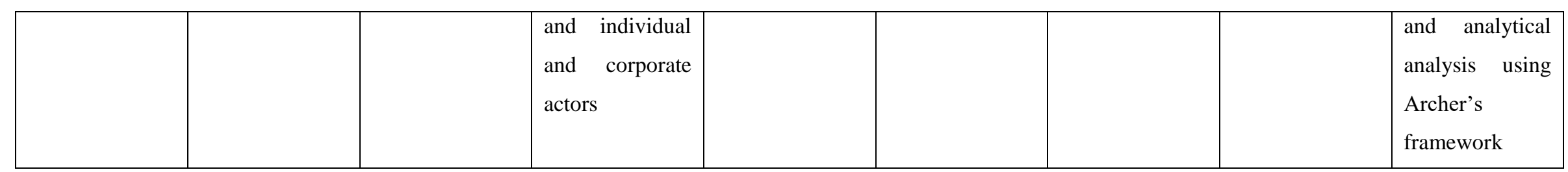

Table 3 Summary of the Use of Mechanisms in Empirical Case Studies 


\section{References}

Aaltonen, A., \& Tempini, N. (2014). Everything counts in large amounts: A critical realist case study on data-based production. Journal of Information technology, 29, 97-110.

Ackroyd, S., \& Fleetwood, S. (2000). Realist Perspectives on Management and Organisations. London: Routledge.

Amar, A. D. (2001). Leading for innovation through symbiosis. European Journal of Innovation Management, 4, 126-133.

Archer, M. (1988). Culture and Agency. Cambridge: Cambridge University Press.

Archer, M. (1995). Realist Social Theory: the Morphogenetic Approach. Cambridge: Cambridge U. P.

Archer, M. (2000). Being Human: The Problem of Agency. Cambridge: Cambridge University Press.

Archer, M. (2003). Structure, Agency and the Internal Conversation. Cambridge: Cambridge University Press.

Archer, M. (2007). Making Our Way Through the World: Human Reflexivity and Social Mobility. Cambridge: Cambridge University Press.

Archer, M., Bhaskar, R., Collier, A., Lawson, T., \& Norrie, A. (1998). Critical Realism: Essential Readings. In. London: Routledge.

Armstrong, D. M. (1999). The open door: Counterfactual versus singularist theories of causation. In H. Sankey (Ed.), Causation and laws of nature (pp. 175-185). Dordrecht: Springer.

Astbury, B., \& Leeuw, F. L. (2010). Unpacking Black Boxes: Mechanisms and Theory Building in Evaluation. American Journal of Evaluation, 31, 363-381.

Avgerou, C. (2013). Social mechanisms for causal explanation in social theory based IS research. Journal of the Association for Information Systems, 14, 399-419.

Bechtel, W., \& Abrahamsen, A. (2005). Explanation: A mechanist alternative. Studies in History and Philosophy of Biological and Biomedical Sciences, 36, 421-441.

Bhaskar, R. (1978). A Realist Theory of Science. Hemel Hempstead: Harvester.

Bhaskar, R. (1979). The Possibility of Naturalism. Hemel Hemstead: Harvester.

Bhaskar, R. (1993). Dialectic: the Pulse of Freedom. London: Verso.

Bhaskar, R. (1994). Plato Etc. London: Verso.

Bhaskar, R. (2002). From Science to Emancipation: Alienation and the Actuality of Enlightenment. London: Sage.

Bhaskar, R. (2010). Contexts of interdisciplinarity: Interdisciplinarity and climate change. In R. Bhaskar, C. Frank, K. G. Høyer, P. Naess \& J. Parker (Eds.), Interdisciplinarity and Climate Change: Transforming Knowledge and Practice for Our Global Future (pp. 1-24). London: Routledge.

Bhaskar, R. (2014). Forward. In P. Edwards, J. O'Mahoney \& S. Vincent (Eds.), Studying Organizations Using Critical Realism: A Practical Guide (pp. v-xv). Oxford: Oxford University Press.

Bhaskar, R., \& Danermark, B. (2006). Metatheory, interdisciplinarity and disability research: a critical realist perspective. Scandinavian Journal of Disability Research, 8, 278-297.

Bhaskar, R., Frank, C., Høyer, K. G., Naess, P., \& Parker, J. (2010). Interdisciplinarity and Climate Change: Transforming Knowledge and Practice for Our Global Future. In. London: Routledge.

Bhaskar, R., \& Hartwig, M. (2010). The Formation of Critical Realism: A Personal Perspective London: Routledge.

Bird, A. (2008). Causal exclusion and evolved emergent properties. In R. Groff (Ed.), Revitalizing Causality: Realism about Causality in Philosophy and Social Science (pp. 163-178). London: Routledge.

Brown, G. (2009). The ontological turn in education: the place of the learning environment. Journal of Critical Realism, 8, 5-34. 
Bunge, M. (2004). How does It work?: The search for explanatory mechanisms. Philosophy of the Social Sciences, 34, 182-210.

Bygstad, B., Munkvold, B. E., \& Volkoff, O. (2016). Identifying generative mechanisms through affordances: a framework for critical realist data analysis. Journal of Information technology, 31, 83-96.

Cartwright, N. (1997). Where do the laws of nature come from? Dialectica, 51, 65-78.

Cartwright, N. (1999). The Dappled World. Cambridge: Cambridge University Press.

Casati, R., \& Varzi, A. (2002). Events. In Stanford Encyclopedia of Philosophy: Stanford University.

Chakravartty, A. (2008). Inessential Aristrotle: Powers without essences. In R. Groff (Ed.), Revitalizing Causality: Realism about Causality in Philosophy and Social Science (pp. 152-162). London: Routledge.

Coleman, J., Katz, E., \& Menzel, H. (1957). The diffusion of an innovation among physicians. Sociometry, 253-270.

Coleman, J. S. (1986). Social theory, social research, and a theory of action. American Journal of Sociology, 1309-1335.

Danermark, B., Ekstrom, M., Jakobsen, L., \& Karlsson, J. (2002). Explaining Society: Critical Realism in the Social Sciences. London: Routledge.

Dewey, J. (1938). Logic: the Theory of Inquiry. New York: Holt.

Dobson, P., Jackson, P., \& Gengatharen, D. (2013). Explaining broadband adoption in rural Australia: modes of reflexivity and the morphogenetic approach. Mis Quarterly, 37, 965-992.

Durand, R., \& Vaara, E. (2009). Causation, counterfactuals, and competitive advantage. Strategic Management Journal, 30, 1245-1264.

Easton, G. (2010). Critical realism in case study research. Industrial Marketing Management, 39, 118128.

Edwards, P., O'Mahoney, J., \& Vincent, S. (2014). Studying Organizations Using Critical Realism: A Practical Guide. In. Oxford: Oxford University Press.

Elder-Vass, D. (2005). Emergence and the realist account of cause. Journal for Critical Realism, 4, 315-338.

Elder-Vass, D. (2010). The Causal Power of Social Structures. Cambridge: Cambridge University Press.

Fleetwood, S. (2009). The ontology of things, properties and powers. Journal of Critical Realism, 8 , 343-366.

Fleetwood, S., \& Hesketh, A. (2010). Explaining the Performance of Human Resource Management. Cambridge: Cambridge University Press.

Gerring, J. (2007). Review article: The mechanismic worldview: Thinking inside the box. British Journal of Political Science, 38, 161-179.

Gibson, J. (1977). The Theory of Affordances. Hillsdale, NJ: Lawrence Erlbaum.

Giddens, A. (1984). The Constitution of Society. Cambridge: Polity Press.

Glennan, S. (1996). Mechanisms and the nature of causation. Erkenntnis, 44, 49-71.

Glennan, S. (2002). Rethinking Mechanistic Explanation. Philosophy of Science, 69, S342-S353.

Goldkuhl, G. (2004). Design theories in information systems - a need for multi-grounding. Journal of Information Technology Theory and Application (JITTA), 6, 59-72.

Goodman, N. (1951). The Structure of Appearance. Cambridge (MA): Harvard University Press.

Gorski, P. S. (2013). "What is Critical Realism? And Why Should You Care?". Contemporary Sociology: A Journal of Reviews, 42, 658-670.

Granovetter, M. (1978). Threshold models of collective behavior. American journal of sociology, 1420-1443.

Gregor, S., \& Hovorka, D. S. (2011). Causality: The elephant in the room in information systems epistemology. In European Conference on Information Systems (Vol. Paper 230): ECIS.

Gregor, S., Müller, O., \& Seidel, S. (2013). Reflection, Abstraction and Theorizing in Design and Development Research. In ECIS 2013. 
Gross, N. (2009). A Pragmatist Theory of Social Mechanisms. American Sociological Review, 74, 358379.

Haavelmo, T. (1943). The statistical implications of a system of simultaneous equations. Econometrics, 11, 1-12.

Hardin, G. (1968). The tragedy of the commons. Science, 162, 1243-1248.

Harre, R., \& Madden, E. (1975). Causal Powers: A Theory of Natural Necessity. Oxford: Blackwell.

Hedström, P., \& Swedberg, R. (1996). Social mechanisms. Acta Sociologica, 39, 281-308.

Hempel, C. (1965). Aspects of Scientific Explanation. New York: Free Press.

Hempel, C., \& Oppenheim., P. (1948). Studies in the Logic of Explanation. Philosophy of Science, 15, $135-175$.

Hendry, D., Leamer, E., \& Poirier, D. (1990). The ET dialogue: a conversation on econometric methodology. Econometric Theory, 6, 171-261.

Henfridsson, O., \& Bygstad, B. (2013). The generative mechanisms of digital infrastructure evolution. Mis Quarterly, 37, 907-931.

Hollis, M. (2002). The Philosophy of Social Science. Cambridge: Cambridge University Press.

Hovorka, D. S., Germonprez, M., \& Larsen, K. R. (2008). Explanation in information systems. Information systems journal, 18, 23-43.

Hume, D. (1978 (orig. 1739)). A Treatise of Human Nature. London: Fontana.

lannacci, F. (2014). Routines, artefacts and technological change: investigating the transformation of criminal justice in England and Wales. J Inf technol, 29, 294-311.

Illari, P., \& Williamson, J. (2011). Causality in the Sciences. In. Oxford: Oxford University Press.

Jones, M., \& Karsten, H. (2008). Giddens's structuration theory and information systems research. Mis Quarterly, 32, 127-157.

Kim, J. (2011). Philosophy of Mind. Boulder, Co: Westview Press.

King, A. (1999). Against structure: A critique of morphogenetic social theory. Sociological Review, 47, $199-227$.

King, A. (2000). The accidental derogation of the lay actor: a critique of Giddens's concept of structure. Philosophy of the Social Sciences, 30, 362-383.

Kwan, K., \& Tsang, E. (2001). Realism and constructivism in strategy research: a critical realist response to Mir and Watson. Strategic Management Journal, 22, 1163-1168.

Laszlo, E. (1972). Introduction to Systems Philosophy : Toward a New Paradigm of Contemporary Thought. N.Y.: Gordon and Breach.

Lawson, T. (1997). Economics and Reality. London: Routledge.

Lee, A. S., \& Baskerville, R. L. (2012). CONCEPTUALIZING GENERALIZABILITY: NEW CONTRIBUTIONS AND A REPLY. Mis Quarterly, 36, 749-A747.

Lee, A. S., \& Hovorka, D. (2015). Crafting theory to satisfy the requirements of interpretation. In 2015 48th Hawaii International Conference on System Sciences (HICSS), (pp. 4918-4927). Hawaii: IEEE.

Leonardi, P. M. (2011). When flexible routines meet flexible technologies: Affordance, constraint, and the imbrication of human and material agencies. Mis Quarterly, 35, 147-167.

Lewis, D. (1973). Counterfactuals. Cambridge, MA: Harvard University Press.

Lewis, D. (2013). Counterfactuals: John Wiley \& Sons.

Lincoln, Y., \& Guba, E. (1985). Naturalistic Enquiry. Thousand Oaks: Sage.

Lipton, P. (2004). Inference to the Best Explanation (2nd ed.). London: Routledge.

Machamer, P. (2004). Activities and causation: The metaphysics and epistemology of mechanisms. International Studies in the Philosophy of Science, 18, 27-39.

Machamer, P., Darden, L., \& Craver, C. F. (2000). Thinking about Mechanisms. Philosophy of Science, 67, 1-25.

Mackie, J. (1977). Dispositions, grounds and causes. Synthese, 34, 361-370. 
Majchrzak, A., Faraj, S., Kane, G. C., \& Azad, B. (2013). The contradictory influence of social media affordances on online communal knowledge sharing. Journal of Computer-Mediated Communication, 19, 38-55.

Manicas, P. (1998). A realist social science. In M. Archer, R. Bhaskar, A. Collier, T. Lawson \& A. Norrie (Eds.), Critical Realism: Essential Readings (pp. 313-338). London: Routledge.

Manicas, P. (2006). A Realist Philosophy of Social Science. Cambridge: Cambridge University Press.

Markus, L. (2004). Fit for function: Functionalism, neofunctionalism and information systems. In J. Mingers \& L. Willcocks (Eds.), Social Theory and Philosophical for Information Systems (pp. 27-55). London: Wiley.

Markus, M. L., \& Robey, D. (1988). Information Technology and Organizational Change: Causal Structure in Theory and Research. Management Science, 34, 583-598.

Merton, R. K. (1948). The self-fulfilling prophecy. The Antioch Review, 8, 193-210.

Mihailescu, M., Mihailescu, D., \& Carlsson, S. (2013). The Conditions of Complex Innovation Adoption Occurrence-A Critical Realist Perspective. Electronic Journal Information Systems Evaluation Volume, 16.

Mingers, J. (1997). Towards critical pluralism. In J. Mingers \& A. Gill (Eds.), Multimethodology: Theory and Practice of Combining Management Science Methodologies (pp. 407-440). Chichester: Wiley.

Mingers, J. (2004). Can social systems be autopoietic? Bhaskar's and Giddens' social theories. Journal for the Theory of Social Behaviour, 34, 403-426.

Mingers, J. (2006). A critique of statistical modelling in management science from a critical realist perspective: its role within multimethodology. Journal Operational Research Society, 55, 202-219.

Mingers, J. (2014). Systems Thinking, Critical Realism and Philosophy: A Confluence of Ideas. London: Routledge.

Mingers, J., Mutch, A., \& Willcocks, L. (2013). Critical Realism in Information Systems Research Mis Quarterly, 37, 795-802.

Mingers, J., \& Willcocks, L. (2014). An integrative semiotic framework for information systems: The social, personal and material worlds. Information and Organization, 24, 48-70.

Mingers, J., \& Willcocks, L. (2017). An integrative semiotic methodology for IS research. Information and Organization, 27, 17-36.

Mirani, R. (2013). A case study of morphogenetic change in long-term offshoring. International Journal of Information Management, 33, 663-673.

Modig, N. (2007). A continuum of organizations formed to carry out projects: Temporary and stationary organization forms. International Journal of Project Management, 25, 807-814.

Morgan, S., \& Winship, C. (2007). Counterfactuals and Causal Inference: Methods and Principles for Social Research. Cambridge: Cambridge University Press.

Mumford, S. (2008). Powers, dispositions, properties or a causal realist manifesto. In R. Groff (Ed.), Revitalizing Causality: Realism about Causality in Philosophy and Social Science (pp. 139151). London: Routledge.

Mutch, A. (2010). Technology, organization and structure - a morphogenetic approach. Organization Science, 21, 507-520.

Njihia, J. M., \& Merali, Y. (2013). The broader context for ICT4D projects: a morphogenetic analysis. Mis Quarterly, 37, 881-905.

O'Mahoney, J., \& Vincent, S. (2014). Critical realism as an empirical project: A beginner's guide. In P. Edwards, J. O'Mahoney \& S. Vincent (Eds.), Studying Organizations Using Critical Realism: A Practical Guide (pp. 1-20). Oxford: Oxford University Press.

Orlikowski, W., \& Baroudi, J. (1991). Studying information technology in organizations: research approaches and assumptions. Information Systems Research, 2, 1-28.

Pawson, R. (2006). Evidence-based policy: A realist perspective. London: Sage publications.

Pawson, R., \& Tilley, N. (1997). Realistic Evaluation. London: Sage. 
Pearl, J. (2000). Causality: Models, Reasoning, and Inference. Cambridge: Cambridge University Press.

Pearl, J. (2009). Causal inference in statistics: An overview. Statistics Surveys, 3, 96-146.

Peirce, C. S. (1905). What pragmatism is. The Monist, 161-181.

Peirce, C. S. (1907). The Charles S. Peirce Papers. In. Cambridge: The Houghton Library, Harvard University.

Peirce, C. S. (1958). Collected Papers of Charles Sanders Peirce (8 Volumes). Cambridge: Harvard University Press.

Peirce, C. S. (1992 ). The Essential Peirce: Selected Philosophical Writings. Indiana University Press: Peirce Edition Project.

Porpora, D. (1998). Do realist run regressions? In 2nd International Centre for Critical Realism Conference. University of Essex.

Pratschke, J. (2003). Realistic models? Critical realism and statistical models in the social sciences. Philosophica, 71, 13-38.

Psillos, S. (2009). An explorer upon untrodden ground: Peirce on abduction. In D. Gabbay, S. Hartmann \& J. Woods (Eds.), Handbook of the History of Logic: Inductive Logic (Vol. 10, pp. 117-151). Amsterdam: Elsevier.

Quine, W. (1970). Philosophy of Logic. Englewood Cliffs (NJ): Prentice-Hall.

Raduescu, C., \& Vessey, I. (2008). Causality in critical realist research: An analysis of three explanatory frameworks. In Proceedings of the International Association for Critical Realism Annual Conference (pp. 11-13).

Raduescu, C., \& Vessey, I. (2009). Methodology in critical realist research: The mediating role of domain specific theory. In AMCIS 2009 Proceedings.

Reed, M. (2009). Critical realism: Philosophy, method or philosophy in search of a method? In D. Buchanan \& A. Bryman (Eds.), The Sage Handbook of Organizational Research Methods (pp. 430-448). London: Sage.

Ron, A. (1999). Regression analysis and the philosophy of social sciences - a critical realist view. In Critical Realism: Implications for Practice. Örebro University Sweden: Centre for Critical Realism.

Rosenberg, A. (2008). Philosophy of Social Science. Boulder, CO: Westview.

Salmon, W. (1971). Statistical Explanation and Statistical Relevance. Pittsburgh: University of Pittsburgh Press.

Salmon, W. (1998). Causality and Explanation. Oxford: Oxford University Press.

Senge, P. (2006). The Fifth Discipline: the Art and Practice of the Learning Organization (2 ed.). London: Century Books.

Shoemaker, S. (1997). Causality and properties. In D. Mellor \& A. Oliver (Eds.), Properties (pp. 228254). New York: Oxford University Press.

Smith, M. (2006). Overcoming theory-practice inconsistencies: Critical realism and information systems research Information and Organization, 16, 191-211.

Steinmetz, G. (1998). Critical realism and historical sociology. A review article. Comparative Studies in Society and History, 40, 170-186.

Symons, J. (2008). Computational models of emergent properties. Minds \& Machines, 18, 475-491.

Toulmin, S. (1958). The Uses of Argument. Cambridge: Cambridge University Press.

Tsang, E., \& Kwan, K. (1999). Replication and theory development in organizational science: a critical realist perspective. Academy of management review, 24, 759-780.

Van Fraassen, B. (1980). The Scientific Image. Oxford: Oxford University Press.

Vincent, S. (2008). A transmutation theory of inter-organizational exchange relations and networks: Applying critical realism to analysis of collective agency. Human Relations, 61, 875-899.

Volkoff, O., \& Strong, D. (2013). Critical realism and affordances: Theorizing IT-associated organizational change processes. Mis Quarterly, 37, 819-834. 
Volkoff, O., Strong, D., \& Elmes, M. (2007). Technological embeddedness and organizational change. Organization Science, 18, 832-848.

Walsham, G. (1993). Interpreting Information Systems in Organizations. Chichester: Wiley.

Walsham, G. (1995). Interpretive case studies in IS research: nature and method. Eur. Journal Inform. Syst., 4, 74-81.

Watson, T. J. (2011). Ethnography, Reality, and Truth: The Vital Need for Studies of 'How Things Work' in Organizations and Management. Journal of Management Studies, 48, 202-217.

Williams, C. K., \& Karahanna, E. (2013). Causal explanation in the coordinating process: A critical realist case study of federated IT governance structures. Mis Quarterly, 37, 933-964.

Woodward, J. (2003). Making Things Happen: A Theory of Causal Explanation. Oxford: Oxford University Press.

Wright, S. (1921). Correlation and causation. Journal of Agricultural Research, 20, 557-595.

Wynn, D., \& Williams, C. K. (2012). Principles for conducting critical realist case study research in information systems. Mis Quarterly, 36, 787-810.

Zachariadis, M., Scott, S., \& Barrett, M. (2013). Methodological implications of critical realism for mixed-methods research. Mis Quarterly, 37, 855-879. 